\author{
Radosław Rek \\ Polskie Towarzystwo Astronomiczne
}

\title{
PLAMY SŁONECZNE PODCZAS MINIMUM MAUNDERA
}

\author{
Sunspots during the Maunder Minimum
}

The first sunspot had been observed with use of a telescope in 1610 by Thomas Harriot, in England. Observations later made by Galileo Galilei and Christoph Scheiner allowed them to publish detailed reviews of the studies.

Very important place in the early history of solar investigations is occupied by Johan Hevelius with his catalogue and pictures of sunspot routes on the solar disc. His research had realized in the years 1642-1644 were the last before the so-called Maunder Minimum that started around 1645 and had lasted until 1715 or 1717 year. The hypothetical physical phenomenon propagated by Gustav Spörer at the end of the $19^{\text {th }}$ century and the observations of sunspots that were discerned during this long minimum are discussed in detail.

This paper presents the history of these solar research and includes some analyses that allowed me to compare the level of solar activity during the second part of the $17^{\text {th }}$ century with other periods. Some observations of sunspots, discerned in the years 1672-1713 and later by other scientists, who were interested in investigations of the heliolatitude changes of these phenomena in the past, were omitted by Spörer on his published list of spots. A large part of other descriptions was connected with an astrometric measurements and misinterpreted as the solar surface investigations. As a result, a false opinion about the level of solar activity during the Maunder Minimum became a natural explanation for the solar behaviour and different terrestrial phenomena as variability of the radiocarbon isotope abundance in tree-rings.

Additionally, this paper presents recently found archival descriptions of the solar spots and descriptions of large sunspots that were visible in the years of deep phase of Minimum, before the year 1700 .

A development of the Minimum idea, with use of the auroral displays discerned in the second part of the $17^{\text {th }}$ century and the first two decades of the next century, is also shortly discussed. The auroral cyclicity appears to confirm more typical course of the solar activity during these years.

Keywords: History of Astronomy, Maunder Minimum

Słowa kluczowe: Historia astronomii, minimum Maundera 


\section{Wstęp: plamy sprzed okresu minimum, czyli pierwsze obserwacje}

Pierwszą plamę słoneczną zaobserwowano z terenu Europy 17 marca $807 \mathrm{r}$. w Lorsch, a zjawisko widoczne było przez $8 \mathrm{dni}^{1}$. Ponad trzysta lat później John z Worcester (zm. 1140) ${ }^{2}$ opisał w swoich kronikach inne plamy, zauważone 8 grudnia $1128 \mathrm{r}^{3}$. Na rysunku wykonanym w czasie obserwacji zaznaczył dwa cienie, z których co najmniej jeden powinien być plamą słoneczną, gdyż obserwowanie równoczesnego tranzytu Merkurego i Wenus w okresie przed wynalezieniem lunety nie mogło być możliwe . Podobne zjawisko, choć pojedyncze, obserwowano potem w 1139 r. w Czechach ${ }^{5}$.

Zarówno przed 807 r., jak i potem, do XVI w., plamy na Słońcu widywano wielokrotnie, głównie w Chinach i Korei ${ }^{6}$. W latach 1603 i 1604 zostały dostrzeżone przez obserwatorów azjatyckich ${ }^{7}$, zaś w Europie plamę obserwował 28 maja 1607 r. Jan Kepler (1571-1630). Podczas pobytu w Pradze czeskiej oglądał tranzyt Merkurego, stosując metodę camera obscura. Wykonał wtedy tylko jeden rysunek cienia znajdującego się na dysku ${ }^{8}$ i nie zorientował się, że zaobserwował plamę, a nie planetę.

Kepler, wydając w 1609 r. opracowanie swojej obserwacji, spodziewał się, że tranzyt Merkurego powinien trwać 6-7 godzin, ale wzmiankował także plamy na Słońcu, które, jak napisał w Phaenomenon singulare seu Mercurius in Sole, mogły być widoczne przez 7, 8 czy 9 dni $^{9}$. Potem, w latach 1611-1613, gdy opublikowano

${ }^{1}$ A.D. Wittmann, Z.T. Xu: A catalogue of sunspot observations from 165 BC to AD 1684, „Astronomy and Astrophysics Supplement Series” t. 70: 1987 s. 88.

${ }^{2}$ Tamże, s. 88-89.

${ }^{3}$ D.M. Willis, F.R. Step he ns o n: Solar and auroral evidence for an intense recurrent geomagnetic storm during December in AD 1128, „Annales Geophysicae” t. 19: 2001 s. 291.

${ }^{4}$ Średnica kątowa planety jest mniejsza niż najmniejszej plamy słonecznej dostrzeżonej współcześnie bez teleskopu. Obserwacje plam tym sposobem opisał B.E. Sch a efer: Sunspot Visibility, „The Quartely journal of the Royal Astronomical Society” t. 32: 1991 s. 35-44.

${ }^{5}$ A.D. Wittmann, Z.T. Xu: dz. cyt. s. 89.

${ }^{6}$ Tamże, s. 88-91.

${ }^{7}$ Tamże, s. 92.

${ }^{8}$ J. Ke ple r: Phaenomenon singulare seu Mercurius in Sole, Lipsk 1609, s. D2, recto.

${ }^{9}$ J. Kepler: Phaenomenon singulare... s. B, recto. Kepler posłużył się relacją o plamie widocznej przez 8 dni w roku 807 (zamieszczoną współcześnie w katalogu: A.D. Wittmann, Z.T. Xu: dz. cyt. s. 88). Ponieważ nie znał wówczas okresu rotacji Słońca nie mógłby wnioskować o tak długim czasie widoczności plamy jedynie na podstawie założenia o ruchu wirowym gwiazdy. W książce E. Reeves, A. Van Helden: On Sunspots: Galileo Galilei and Christoph, Chicago 2010, znalazła się uwaga, że relacja ta została zniekształcona przez samego Keplera, który pisząc Astronomiae pars optica zmienił rok widoczności zjawiska z 807 na 808 (taka dwuznaczność rzeczywiście pojawia się w Phaenomenon) i miałby także inaczej zinterpretować sam opis. Na podstawie: T. Si e rotowicz: O położeniu plam słonecznych, Tarnów 2013, s. 338. Jednak, o ile w oryginalnym fragmencie Astronomiae pars optica Kepler wzmiankuje jedynie tranzyt Merkurego to w Phaenomenon singulare seu Mercurius in Sole wyraźnie odróżnił krótkotrwałe, w porównaniu z czasem widoczności plam, zjawisko tranzytu od plam 
De maculis in Sole observatis Fabriciusa, a także listy przesłane do Marka Welsera (1558-1614) przez Scheinera i Galileusza, wydał m.in. Dioptrice, zawierającą opis teleskopu odwracającego ${ }^{10}$, ale nie wziął wówczas udziału w dyskusji o plamach słonecznych. Dopiero w 1617 r., we wstępie do efemeryd na ten rok, Kepler dał wyraz swojemu zadowoleniu z zaobserwowania plamy przed Galileuszem ${ }^{11}$, pisząc najpewniej o zjawisku widocznym w maju $1607 \mathrm{r}$.

Poprzez lunetę pierwsze plamy słoneczne zaobserwował w grudniu $1610 \mathrm{r}$. Thomas Harriot (1560-1621) w Anglii ${ }^{12}$, a później dostrzegli je Christoph Scheiner (1573-1650), Galileo Galilei (1564-1642) i Johann Fabricius (1587-1615).

Mimo że Harriot cienie na Słońcu zaobserwował już pod koniec 1610 r. $^{13}$, pierwszy opublikowany mało dokładny rysunek plam dostrzeżonych przez teleskop datowany jest dopiero na 21 października $1611 \mathrm{r}$. Wykonany został przez Christopha Scheinera. Rysunki o większej średnicy powstałe podczas galileuszowych obserwacji w roku 1612 i zamieszczone potem w Istoria e dimostrazioni ${ }^{14}$ są już znacznie bardziej szczegółowe; patrz rysunek 1.

Scheiner pozostawił wiele ilustracji plam słonecznych, wykonanych głównie w latach 1625-1627, a oprócz listów ${ }^{15}$ napisał również dwie książki na ten temat ${ }^{16}$ i jako pierwszy wyznaczył wielkość nachylenia słonecznej osi rotacji do ekliptyki ${ }^{17}$. Rysował ich tory na tarczy, zamieszczając potem w dziele Rosa Ursina ${ }^{18}$ (rysunek 2), które ukazało się dwa lata przed Dialogiem Galileusza ${ }^{19}$. W Dialogu nie pojawiły

obserwowanych na tarczy słonecznej przez kilka dni. Wzmianka o Merkurym, a nie plamie, widocznym na dysku słonecznym w 807 r. znalazła się natomiast w innym, wcześniej wydanym, jego dziele: J. Ke pler: Ad Vitellionem paralipomena, quibus astronomiae pars optica traditur, Frankfurt 1604, s. 306.

${ }^{10}$ O. Gi nge rich: Johannes Kepler [w:] The general history of astronomy, tom 2, część A, red. M. Hoskin, Cambridge 1989, s. 70-71.

${ }^{11}$ Tamże, s. 70.

${ }^{12}$ Galileusz być może obserwował plamy już latem 1610 r. w Padwie; W.M. Mitchell: The history of the discovery of the solar spots, „Popular Astronomy” t. 24: 1916 s. 30 i 85.

${ }^{13}$ Harriot przygotował szereg rysunków obserwując Słońce między 1 grudnia 1611 a 18 styczniem 1613 r. kalendarza juliańskiego; R.B. Herr: Solar Rotation Determined from Thomas Harriot's Sunspot Observations of 1611 to 1613, „Science” t. 202: 1978 s. 1079-1081.

${ }^{14} \mathrm{G}$ a li l e u $\mathrm{z}$ : Istoria e dimostrazioni intorno alle macchie solari e loro accidenti comprese in tre lettere scritte all' illustrissimo Signor Marco Velseri Linceo duumviro d'augusta consigliero di sva maesta cesarea dal Signor Galileo Galilei Linceo, Rzym 1613, s. 40-60.

${ }^{15} \mathrm{Ch}$. Sch ein er: De maculis solaribus tres epistolae, Rzym 1613.

${ }^{16}$ Tytuł drugiego dzieła: Ch. Schein er: Prodromus pro sole mobili, et terra stabili, contra academicum florentinum Galilaeum a Galilaeis, Praga 1651.

17 Galileusz twierdził, że efekt zauważył wcześniej. Według: W.M. Mitchell: dz. cyt. s. $488-489$.

${ }^{18} \mathrm{Ch}$. Sch ein er: Rosa Ursina, Bracciani 1630.

${ }^{19}$ Galileusz: Dialogo di Galileo Galilei, Florencja 1632. Tytuł współczesnego wydania polskiego: Dialog o dwu najważniejszych układach świata: ptolemeuszowym i kopernikowym, Warszawa 2004; tłum. E. Ligocki. 
się już żadne rysunki z obserwacji powierzchni Słońca, choć zmiany kształtu torów plam słonecznych, spowodowane nachyleniem słonecznej osi rotacji, zostały przedyskutowane ${ }^{20}$.

Karol Malapert (1581-1630) opracował swoje obserwacje w podobny sposób jak zrobił to Scheiner, w tym te wykonane w Kaliszu, pisząc dzieło Austriaca sidera heliocyclia astronomicis hypothesibus illigata ${ }^{21}$, które zostało wydane dopiero w 1633 r.. W książce zamieszczona została także czytelna ilustracja zmian nachylenia osi rotacji słonecznej, obserwowanych z kardynalnych pozycji ziemskiej orbity.

Pierwsza polska rozprawa naukowa, w której opisano plamy słoneczne, ukazała się nawet wcześniej, bo w 1626 r., jako praca szesnastoletniego wówczas Jana Mikołaja Smoguleckiego (1610-1656). W liczącym ponad 120 stron dziele zamieszczony został katalog plam, które zaobserwował w $1625 \mathrm{r}^{22}$.
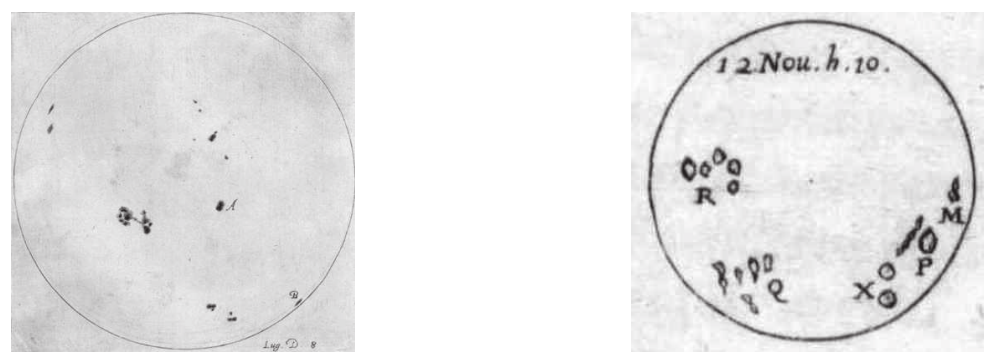

Rysunek 1. Przykłady obserwacji plam słonecznych wykonanych w pierwszej połowie XVII w. przez Galileusza w sierpniu 1612 r. (z lewej) ${ }^{23}$ oraz Scheinera w listopadzie 1611 r. $^{24}$, na którego rysunku plamy lokują się wzdłuż obwodu tarczy słonecznej. Pierre Gassendi (1592-1655) podobnie surowe grafiki, choć z dokładnością bliższą galileuszowym, wykonywał jeszcze w latach trzydziestych. Za zgodą Biblioteki Uniwersytetu Warszawskiego.

Liczne plamy obserwował przez lunetę w 1612 r. Galileusz. Kunitomo Sakurai wyznaczył współcześnie wartości liczb Wolfa dla poszczególnych dni, analizując wykonane wówczas przez Włocha rysunki zamieszczone w Istoria e dimostrazioni ${ }^{25}$. Średnia liczba Wolfa ustalona na podstawie ilustracji wykonanych z przerwami mię-

20 Tamże (wydanie polskie), s. 534-539.

${ }^{21}$ Ch. Malapert: Austriaca sidera heliocyclia astronomicis hypothesibus illigata, Douai 1633; rysunki wykonane w Kaliszu znajdują się na stronach: 70 (9 marca 1618 r.), 74 (7-18 lipca 1618 r.) i 75 (8-19 lipca 1618 r.).

22 J.M. Smogulecki: Sol illustratus ac propugnatus ab Illustri ac Generoso Domino, Domino Ioanne Nicolao a Smogulecz Smogulecki, \&c. Maioris Congregationis Academicae Friburgi Brisgoiae Praefecto, Mathematicarum Scientiarum, atque Philosophiae Studioso, 1626 Fryburg. Plamy obserwował w miesiącach: styczeń-luty, kwiecień-czerwiec, sierpień-październik. Na jednej ze stron jego książki znalazło się sześć rysunków prezentujących położenia plam na tarczy słonecznej w kolejnych dniach; J.M. Sm ogule cki: dz. cyt. s. 45.

${ }^{23}$ Galile us z : Istoria e... s. 93.

${ }^{24} \mathrm{Ch}$. Scheiner: De maculis... wklejka.

${ }^{25}$ K. Sakurai: The solar activity in the time of Galileo, „Journal for the History of Astronomy" t. 11: 1980 s. 164-173. 
dzy 2 czerwca a 20 sierpnia sięgnęła stu, choć niektóre wartości dzienne okazały się większe, jak 26 czerwca, gdy liczba dobowa była równa $153^{26}$. Najwyraźniej odkrycie plam słonecznych nastąpiło tuż przed lub w czasie szczytu ich liczby, zaś Kepler plamę obserwował podczas minimum cyklu jedenastoletniego.

Lata drugiej połowy wieku, począwszy od 1645 r. to natomiast okres tzw. Minimum

Maundera, które według wielu współczesnych badaczy miałoby być czasem znacznie mniejszej aktywności plamowej Słońca i trwać do $1715 \mathrm{r}$. Temat ten jest szczegółowo referowany w dalszej części artykułu.
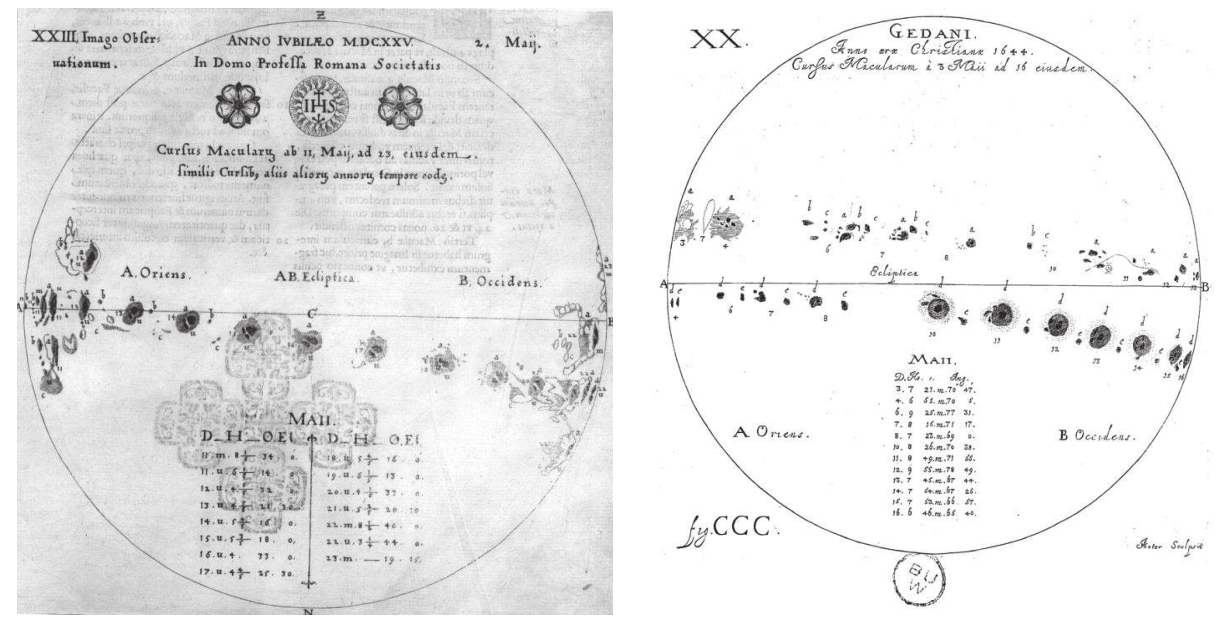

Rysunek 2. Obserwacje późniejsze. Podobieństwo przedstawiania plam słonecznych przez Scheinera w Rosa Ursina ${ }^{27}$ i Heweliusza w Selenographia ${ }^{28}$. Obydwaj zamiast obrazu tarczy słonecznej zamieszczali rysunki torów wybranych plam i grup plam na tarczy. Pojedyncze ilustracje nie umożliwiają wyznaczenia liczb Wolfa. Za zgodą Biblioteki Uniwersytetu Warszawskiego.

\section{Instrumenty i metody obserwacyjne}

Wynalezienie lunety miało duże znaczenie także dla badań słonecznych, gdyż przyrząd umożliwił m.in. obserwacje powierzchni dziennej gwiazdy z wykorzystaniem ekranu ${ }^{29}$. W ten sposób powstał heliotrop, czyli teleskop na montażu paralaktycznym zapożyczonym wprost z torkwetum, skonstruowany w Kaliszu z inicjaty-

${ }^{26}$ Tamże, s. 168.

${ }^{27}$ Rysunek plamy widocznej w 1625 r.; Ch. Sch ein er: Rosa... s. 211.

${ }^{28}$ Plama obserwowana w 1644 r.; J. Heweliusz: Selenographia sive lunae descriptio, Gdańsk 1647, rysunek między numerowanymi stronami 518 i 519.

${ }^{29}$ Rysunki prezentujące metodę obserwacji powierzchni Słońca zostały zamieszczone np. w: Ch. Sc hein er: Rosa..., s. 77, J. H e weli u sz: Selenographia sive...; dwa rysunki między stronami 98 i 99 oraz 102 i 103, Ch. Malapert: dz. cyt. s. 21, a także J. Heweliusz: Machina coelestis, Gdańsk 1673, ks. I, ilustracje między s. 372 i 373 oraz 374 i 375. 
wy Malaperta ${ }^{30}$. Rzutowanie obrazu zastąpiło wcześniejszą metodę obserwacyjną, polegająca na montowaniu w lunecie kolorowych szkieł słabo przepuszczających światło, czyli tzw. helioskop.

Projekcję na ekran stosował już Galileusz, o której dowiedział się od Benedetto Castelliego (1578-1643), co zostało opisane w drugim liście do Marka Welsera $^{31}$. Z innego listu, napisanego 11 grudnia 1612 r. przez Odona van Maelcote (1572-1615) do Keplera, wynika, że wcześniej pokazywał plamy słoneczne innym sposobem niż rzutowanie ${ }^{32}$.

Z metody projekcji korzystał potem w latach 1642-1644 Jan Heweliusz (1611$1687)^{33}$, natomiast autorzy szeregu późniejszych publikacji sposobu takiego nie wzmiankują, ograniczywszy się jedynie do informacji o długości lunety. Ani artykuł Gian Domenica Cassiniego (1625-1712) z $1671 \mathrm{r}^{34}$, ani Johna Flamsteeda (1646-1719) z 1676 r. $^{35}$, gdzie obydwaj po raz pierwszy opisali dostrzeżone przez siebie plamy, nie informuje o rzutowaniu obrazu Słońca na ekran. 0 tym, że metodę tę stosował Anglik, wiadomo z listu, który 8 lipca 1684 r. napisał do Edwarda Barnarda ${ }^{36}$. Szczegół ten musiał wydawać się nieistotny zarówno dla Heweliusza tworzącego katalog plam, które zaobserwował w późniejszym okresie, czyli w latach 1653-1671 ${ }^{37}$, jak również dla Stannyana ${ }^{38}$, obserwującego rozbudowaną grupę plam w schyłkowej fazie Minimum Maundera. Także publikacja Ribesów (Jean Claude Ribes i Elizabeth Nesme-Ribes (1942-1996)), opisująca szczegóły wyznaczania średnicy kątowej Słońca mikrometrem przez Jeana Picarda (1620-1682) i zmodyfikowaną metodą tranzytów stosowaną przez

${ }^{30}$ K.M.P. Rudnicki: Jezuicki wynalazek paralaktycznego montażu teleskopów [w:] Wkład jezuitów do nauki i kultury w Rzeczypospolitej Obojga Narodów i pod zaborami, red. I. Stasiewicz-Jasiukowa, Kraków 2004, s. 324-326.

${ }^{31}$ Tłumaczenie listu: T. Si er otowicz: dz. cyt. s. 334-336.

${ }^{32}$ W.M. Mitchell: dz. cyt. s. 296.

${ }^{33}$ J. He weliu sz: Selenographia sive... rysunek między stronami 98-99.

${ }^{34}$ G.D. Cas sini: New Observations of Spots in the Sun; made at the Royal Academy of Paris, the 11, 12 and 13th of August 1671; and English't out of the French, as follows, „Philosophical Transactions" t. 6: 1671 s. 2250-2253; Tenże: The Observations of the SPOTS of the SUN, made at the Royal Academy at Paris, Continued; and English't out of French, „Philosophical Transactions" t. 6: 1671 s. 3020-3024.

${ }^{35} \mathrm{~J}$. Fla mste ed, E. Halley: An Extract of an account given by Mr. Flamstead of his own and Mr. Edmund Halleys Observations concerning the Spots in the Sun, appearing in July and August 1676, „Philosophical Transactions” t. 11: 1676 s. 687-688.

${ }^{36} \mathrm{~J}$. Fl a m s te ed: The correspondence of John Flamsteed, the first Astronomer Royal, t. 2 (lata 1682-1703), red. E.G. Forbes i in., Bristol i Philadelphia 1997, s. 176-177, list 519.

${ }^{37}$ J. Heweliu sz: Machina coelestis, Gdańsk 1679, ks. III, s. 1-30.

${ }^{38}$ Nie jest znane imię Stanyanna. Nie wiadomo też kiedy się urodził; Stannyan: Observations made by Captain Stannyan of the Spots that appear'd upon the Body of the Sun in the Months of May, June and July, in the year 1704. Communicated by Mr Hodgson, F. R. S., „Philosophical Transactions" t. 24: 1704-1705 s. 1756-1762. 
Philippe de La Hire'a (1640-1718), nie precyzuje czy obraz dziennej gwiazdy uzyskiwany był w wyniku rzutowania na ekran, czy inaczej ${ }^{39}$.

Średnice lunet używanych przez XVII w. astronomów były stosunkowo nieduże. Wiadomo np. o aperturze długiej czternastostopowej lunety Flamsteeda, której używał do obserwacji Saturna, że była taka, jak największego teleskopu Galileusza - 38 $\mathrm{mm}^{40}$. Wiadomo też, że do celów obserwacji astrometrycznych Picard stosował lunetę o długości 6 stóp i uzyskiwał obraz tarczy słonecznej o średnicy około $2 \mathrm{~cm}^{41}$, z czego wynika, że dokonywał pomiarów bez zamontowanego okularu ${ }^{42}$, a pozycje dostrzeżonych wówczas plam wyznaczał potem lunetą o połowę krótszą ${ }^{43}$. Nicolas Bion (1652-1733), konstruktor instrumentów w Obserwatorium Paryskim, obserwując przez teleskop o tej samej długości otrzymał już znacznie większy obraz dysku słonecznego, o którego wielkości można wnioskować na podstawie ryciny zamieszczonej w jego książce; patrz rys. 5.

Inna luneta stosowana przez Picarda do pomiarów wysokości kątowej górnej i dolnej krawędzi Słońca oraz wysokości kątowej plam teoretycznie powinna umożliwiać dokładność sięgająca 5", co jest równoznaczne z rozróżnianiem w okolicy równika dysku dziennej gwiazdy szczegółów o rozciągłości równej pół stopnia szerokości heliograficznej ${ }^{44}$. Jednak niewielkiej, a często całkiem dużej plamy, zwłaszcza z rozmytym półcieniem, nie udałoby się wcześniej dostrzec na obrazie tarczy o małej średnicy uzyskiwanym lunetą Picarda, stosowaną do pomiarów średnicy kątowej dziennej gwiazdy.

Zestawienia obserwacji pozycyjnych wykonanych przez Picarda oraz de La Hire'a, zamieszczone w opracowaniu Pierre'a Charlesa Le Monniera (1715-1799) ${ }^{45}$, umożliwiają wyznaczenie torów plam na widocznej półsferze Słońca i mogą potwierdzić dokładność wykonywanego pomiaru, którego precyzja czasem okazywała się znacznie mniejsza. Badania szczegółów ich struktury zauważonych podczas obserwacji astrometrycznych wykonywane były zawsze lunetą o znacznie dłuższej ogniskowej, a zatem również większym powiększeniu. Długości tych lunet można

${ }^{39}$ J.C. Ribes, E. N es me-Ribes: The solar sunspot cycle in the Maunder minimum AD 1645 to AD 1715, „Astronomy and Astrophysics” t. 276: 1993 s. 549-563.

${ }^{40} \mathrm{~J}$. Fl a m ste e d: The correspondence of John Flamsteed, the first Astronomer Royal, t. 1 (lata 1666-1682), red. E.G. Forbes i in., Bristol i Philadelphia 1995, s. 121-122, list o numerze 77 z 2 grudnia 1671 r. napisany przez Flamsteeda do Oldenburga.

${ }^{41}$ E. Ribes, J.C. Ribes, R. Barthalot: Evidence for a larger Sun with a slower rotation during the seventeenth century, „Nature” t. 326: 1987 s. 52.

${ }^{42}$ Luneta o długości 6 stóp powinna wytwarzać w ognisku obiektywu obraz Słońca o średnicy około 18 milimetrów; szczegóły obliczeń w: A. Wo s zczy k: Instrumenty Kopernika a narzędzia współczesnej astronomii, Toruń 1973, s. 64.

${ }^{43}$ J.C. Ribes, E. Nesme-Ribes: The solar... s. 554 i 555.

${ }^{44}$ Tamże, s. 554 i 555.

${ }^{45}$ P.C. Le Monnier: Histoire celeste ou recueil de toutes les observations astronomiques faites par ordre du Roy, Paryż 1741, s. 23-24 i 85-328. 
odnaleźć np. na rysunkach plam wykonanych przez de La Hire’a (16 stóp) ${ }^{46}$ i Biona (20 stóp) ${ }^{47}$, który wyznaczył tor grupy na tarczy używając lunety kilkakrotnie krótszej, o długości 6 stóp.

Zachowana korespondencja pozwoliła także ustalić, że np. w lutym 1672 r. Flamsteed obserwował Słońce lunetą o długości 164,5 cala ${ }^{48}$, zaś na samym początku katalogu plam w Historia coelestis Britannica wzmiankowana jest ponadto luneta o długości 8 stóp ${ }^{49}$ oraz 16 stopowa ${ }^{50}$, jak również teleskop krótszy ${ }^{51}$ i dłuższy ${ }^{52}$ w dalszej części podrozdziału dzieła. Na pewno instrumentem o długości 16 stóp astronom posługiwał się obserwując zaćmienia słoneczne ${ }^{53}$.

W schyłkowym okresie Minimum Maundera, w 1704 r., 7- i 18-stopowej lunety używał Stannyan ${ }^{54}$, zaś teleskopami długimi na 6 i 16 stóp obserwował William Derham (1657-1735) 55 . Podobnie Gian Domenico Cassini, gdy rysował szczegóły swojej pierwszej grupy plam dostrzeżonej w sierpniu $1671 \mathrm{r}^{56}$ przyrządem o ogniskowej około 3 stóp ${ }^{57}$, korzystał z większej lunety, długiej na 17 stóp ${ }^{58}$.

Ponieważ znane jest powiększenie uzyskiwane w połowie XVII w. dużym teleskopem Christiaana Huygensa (1629-1695) o długości 3,5 metra ${ }^{59}$ to można wnioskować o ogniskowej okularu i przypuszczać, że ówczesna luneta o długości 6 stóp mogła dysponować powiększeniem około 27-krotnym. Dłuższe lunety, o ogniskowej od 16 do 18 stóp, przy podobnej długości ogniskowej okularu, jak w lunecie Holendra, uzyskiwałyby wtedy powiększenie kątowe 70- lub 80-krotne.

Użytecznym dla obserwacji słonecznych przy użyciu teleskopu okazało się wynalezienie w roku 1639 mikrometru przez Williama Gascoigne'a (16121644). Dzięki zastosowaniu przyrządu możliwe było wyznaczenie wielkości

46 Tamże; plansza 4.

${ }^{47}$ N. B i o n: Des observations des Taches du Soleil [w:] L'usage des globes célestes et terrestres, et des sphéres suivant les différens systémes du monde, Paryż 1717, ks. III, s. 376.

${ }^{48}$ J. Flam steed: The correspondence..., t. 1, s. 132, list o numerze 85.

${ }^{49}$ Tenże: Historia coelestis Britannica, Londyn 1725, ks. I, s. 361-366.

50 Tamże, ks. I, s. nienumerowana między 362 i 363.

51 Tamże; relacja z 5 na 6 grudnia (kalendarz juliański z początkiem doby w południe): „Tubum breviorem ad Solem adhibui, \& Maculam regressam intra discum vidi”, s. nienumerowana między 362 i 363.

52 Tamże, łac. „tubo longiore” w opisie z 7 grudnia, s. 365.

${ }^{53}$ J. Flam stee d: The correspondence..., t. 2, s. 176-177, list 519.

${ }^{54}$ Stannyan: dz. cyt. s. 1756-1762.

${ }^{55}$ W. De r h a m: Observations upon the Spots that have been upon the Sun, from the Year 1703 to 1711, „Philosophical Transactions” t. 27: 1710 s. 272.

${ }^{56}$ G.D. Cas sini: New Observations... s. 2251.

57 Także w „Memoires de mathématique et de physique tirés des registres de l'Académie Royale des Sciences" z lat 1702-1703, oprócz kilku innych, wzmiankowana bywa taka luneta.

${ }^{58}$ G.D. Cassini: New Observations... s. 2250-2253.

${ }^{59} \mathrm{~J}$. N or th: Historia astronomii i kosmologii, Katowice 1997, s. 234. 
kątowej niektórych plam przez samych obserwatorów oraz pomiar ich odległości od brzegu tarczy słonecznej. Heweliusz, katalogując swoje obserwacje, nie zamieścił wyników takich pomiarów, ale z przyrządu korzystał zarówno Picard ${ }^{60}$, jak i Flamsteed ${ }^{61}$.

\section{Plamy okresu minimum Maundera}

W roku 1976 amerykański geofizyk John Eddy (1931-2009) nazwał długie minimum liczby plam przypadające na lata 1645-1715 nazwiskiem Edwarda Maundera (1851-1928). Idea trwającego siedemdziesiąt lat okresu zmniejszonej lub zmienionej aktywności słonecznej powstała jednak wcześniej, w latach 1887-1889, a pomysłodawcą był niemiecki astronom Gustaw Spörer (1822-1895) ${ }^{62}$. Także Rudolf Wolf (1816-1893), badając wtedy opisy archiwalne, nie znalazł plam na północnej półkuli Słońca w tym okresie ${ }^{63}$. Poglądem Spörera zainteresował się wówczas Maunder, jak również Agnes Clerke (1842-1907) ${ }^{64}$, a później Andrew E. Douglass (1867-1962) ${ }^{65}$, astronom i twórca dendrochronologii, któremu przy wykorzystaniu własnych spostrzeżeń z zakresu botaniki udało się początkowo potwierdzić długotrwałe minimum.

Temat pojawił się potem ponownie na łamach prasy naukowej dopiero w $1922 \mathrm{r}$. gdy Maunder ${ }^{66}$ opublikował kolejne opracowanie, zamieszczając listę podobną do tej, którą w roku 1889 zaprezentował Spörer ${ }^{67}$. Znalazły się tam wszystkie skatalogowane wcześniej plamy z przeważnie takimi samymi, jak ustalone przez astronoma niemieckiego, wartościami szerokości heliograficznej.

${ }^{60}$ J.C. Ribes, E. Ne sme-Ribes: The solar... s. 552-554.

${ }^{61} \mathrm{~J}$. Fla mstee d: Historia coelestis..., ks. I, s. 361-366.

${ }^{62}$ G. Spö re r: Ueber die Periodicität der Sonnenflecken seit dem Jahre 1618, vornehmlich in Bezug auf die heliographische Breite derselben, und Hinweis auf eine erhebliche Störung dieser Periodicität während eines langen Zeitraumes, „Vierteljahresschrift Astronomische Gesselshaft (Leipsig)" t. 22: 1887 s. 328.

${ }^{63}$ R. Wolf: Besprechung der neuesten Untersuchungen von Herrn Professor Dr. Spörer über die Wanderung der Fleckenzonen, „Astronomische Mittheilungen von Dr. Rudolf Wolf” z. 73: 1889 maj s. 86.

${ }^{64}$ A.M. Cler ke: A prolonged sunspot minimum, „Knowledge” t. 17: 1894 s. 206-207.

${ }^{65}$ Związek między małą liczbą plam a mniejszymi szerokościami rocznych przyrostów drzewnych stwierdził, jak wynika z jego artykułu, już w roku 1919. A.E. Douglass: Solar records in tree growth, "Journal of the Royal Astronomical Society of Canada" t. 21: 1927 s. 277-279.

${ }^{66}$ E.W. M a u n d e r: The Prolonged Sunspot Minimum, 1645-1715, „The Journal of the British Astronomical Association" t. 32: 1922 s. 140-145.

${ }^{67}$ G. Spö re r: Ueber die Periodicität der Sonnenflecken seit dem Jahre 1618, vornehmlich in Bezug auf die heliographische Breite derselben, und Nachweis einer erheblichen Störung dieser Periodicität während eines langen Zeitraumes, „Nova Acta der Kaiserliche Leopoldinisch Carolinische Deutschen Akademie der Naturforscher" t. 53: 1889 nr 2 s. 319-324. 
Najbardziej znanymi obserwatorami plam słonecznych okresu Minimum byli: Jan Heweliusz (zauważył plamy w latach: $1652^{68}, 1653$ i 1654 (liczne), 1657, 1659, 1660 (liczne), 1661, 1671 ${ }^{69}, 1684^{70}$ ), John Flamsteed (obserwował plamy w drugiej połowie 1676 r., jedną w 1684 r. i trzy dostrzegł w roku 1703), ale również Jean Picard (obserwował Słońce głównie w Paryżu do roku 1677, w 1681 r. i w pierwszych miesiącach 1682 r. $^{71}$ ), Phillippe de La Hire, Nicolas Bion (obserwował w 1672 r.), Gian Domenico Cassini (obserwował plamy np. w roku 1671 i kilkakrotnie w 1678 (rys. 4), czy dużą w 1680 r. $^{72}$, a przypuszczalnie także opisaną przez Flamsteeda w 1684 r.) i Gottfried Kirch (1639-1710) (np. dwie lub trzy plamy dostrzegł 23 maja 1678 r., jak również duże widoczne w 1687 r.). Tematem plam zajmowało się ponadto wielu innych ówczesnych badaczy np. Robert Boyle (1627-1691) ${ }^{73}$, Robert Hooke (1635-1702) ${ }^{74}$ i Stannyan ${ }^{75}$; wyniki wszystkich trzech znane są z publikacji w „Philosophical Transactions”.

Plamy obserwował i katalogował także Derham, który w tym samym czasopiśmie zamieścił obszerną listę własnych obserwacji oraz Johann Abraham Ihle (1627-1704), dzielący się swoimi spostrzeżeniami w korespondencji i Georg Christoph Eimmart (1638-1705) ${ }^{76}$, o którym wiadomo, że wykonywał podobne

${ }^{68} \mathrm{~J}$. H e welius z: llustribus Viris, Petro Gassendo et Ismaeli Bullialdo, philosophis ac mathematicis nostri saeculi summis, amicis suis officiose honorandis Johannes Hevelius S., Gdańsk 1652, s. 8. List ten znany jest również pod innym tytułem: Illustrissimis Viris Pet. Gassendo et Ismael Bullialdo de eclipse solari.

${ }^{69}$ Tenże: Machina coelestis..., ks. III, s. 1-30.

${ }^{70}$ Tenże: Annus climactericus sive rerum Uranicarum observationum annus quadragesimus nonus, Gdańsk 1685, s. 186.

${ }^{71}$ Opracowanie wszystkich obserwacji wykonanych przez Picarda w 1676 r. zajęło w katalogu Le Monniera 56 stron, spostrzeżenia 1678 r. zmieściły się już tylko na trzech stronach, zapisy 1679 r. zajęły 2,5 strony, a 1680 r. trzy strony. W 1681 r. Picard obserwował częściej i jego spostrzeżenia zapełniły już trzynaście stron, zaś w 1682 r. jedenaście. Na podstawie P.C. Le Monnier: dz. cyt. s. 173-267.

${ }^{72}$ [Komunikat bez tytułu i nazwiska autora]: „Histoire de l’Académie Royale des Sciences” t. 1: 1733 s. $317-318$.

${ }^{73}$ R. B oyle: An Intimation of divers Philosophical particulars, now undertaken and consider'd by Several Ingenious and Learned men; here inserted to excite others to joyn with them in the same or the like Attempts and Observations, „Philosophical Transactions” t. 6: 1671 s. 2216-2217.

${ }^{74}$ R. H o o ke: Observations made by Mr. Hook, of some Spots in the Sun, return'd after they had passed over the Upper Hemisphere of the Sun which is hid from Us; according as was predicted, „Philosophical Transactions” t. 6: 1671 s. 2295-2296.

${ }^{75}$ Stannyan: dz. cyt. s. $1756-1762$.

${ }^{76}$ G.Ch. Eimmart miał obserwować plamy w latach 1682 i 1683, co stanowi treść przypisu w czasopiśmie Wolfa z numerem 93 (R. Wolf: Scheibel, Einleitung zur mathematischen Bücherkenntniss, „Mittheilungen über die Sonnenflecken” z. 6: 1858 luty s. 156-157), natomiast z katalogu D. Hoyta i K. Schattena wynika, że badacz dostrzegł wtedy tylko jedną; ftp.ngdc. noaa.gov/STP/SOLAR_DATA/SUNSPOT_NUMBERS/GROUP_SUNSPOT_NUMBERS/alldata (obecnie niedostępny). Natomiast znacznie większe liczby dni widoczności plam, wzmiankowane w moim wcześniejszym artykule (R. Rek: Obserwacje plam słonecznych w wieku XVII, „Kwartalnik Historii Nauki i Techniki” t. 50: 2005 nr 3-4, s. 236), okazały się numerami przy- 
obserwacje na podstawie przypisów bibliograficznych zaczerpniętych z czasopisma wydawanego przez Wolfa.

Wiele archiwalnych relacji z obserwacji wykonanych w latach Minimum Maundera zostało skatalogowanych właśnie w „Mitteilugen über der Sonnenflecken” i „Astronomische Mitteilungen von Dr. Rudolf Wolf”. Pierwszy zeszyt wydawanego przez Szwajcara czasopisma ukazał się w 1856 r., zaś przegląd publikacji dotyczących Słońca, w tym także XVII-wiecznych, zamieszczany był systematycznie w kolejnych numerach i dostarcza licznych wzmianek o źródłach.

Według Františka Linka (1906-1984) ${ }^{77}$ Picard i de La Hire w latach 1672-1677 oraz 1684-1700 obserwowali plamy przez 83 dni, przy czym wiadomo, że po obserwacji plamy w 1695 r. przez Giacomo Filippo Maraldiego (1665-1729) do 7 listopada 1700 r. nie zaobserwowano już żadnej. Natomiast z opracowania Ribesów wynika, iż w latach 1671-1695 dostrzeżono w Obserwatorium Paryskim 51 plam ${ }^{78}$, zaś z katalogu Le Monniera, że w latach 1672-1684 plamy były widoczne przez 58 dni $^{79}$. Obserwacje wykonane podczas pięciu innych dni zostały skatalogowane jedynie na zamieszczonych w tym dziele ilustracjach. Wśród 20 dni, które nie zostały zebrane przez Le Monniera, zarówno w tabelach, jak i na rysunkach, a są wzmiankowane przez Linka ${ }^{80}$, znalazłoby się aż 18 dni, podczas których plamy słoneczne zauważył Cassini. Wiadomo, że były to plamy dostrzeżone w latach: 1676, 1678, 1680 i 1684, w tym cztery dni będące uzupełnieniem kilkudniowej sekwencji obserwacji wykonanych przez de La Hire'a w maju $1684 \mathrm{r}^{81}$. Sam de La Hire spoglądał potem na plamy również: 23, 28, 29 i 30 kwietnia oraz 1 maja $1686 r^{82}$. Jednak wśród wcześniej widocznych zjawisk, które obserwował w 1684 r., a skatalogowanych potem przez Le Monniera, można doliczyć się jedynie połowy ze wzmiankowanych przez Ribesów; w latach 1672-1684 zaobserwowano zatem 17, a nie 31 plam.

pisów bibliograficznych zaczerpniętymi z czasopisma Wolfa, które Link zamieścił w swoim tekście; F. Lin k: Solar cycles between 1540 and 1700, „Solar Physics” t. 59: 1978 s. 176.

${ }^{77}$ F. Lin k: Solar cycles... s. 176.

${ }^{78}$ J.C. Ribes, E. Nesme-Ribes: The solar... s. 556.

${ }^{79}$ P.C. Le Monnier: dz. cyt. s. 23-24 i 85-328.

${ }^{80}$ F. Lin k: Solar cycles... s. 176.

${ }^{81}$ Według Spörera Cassini obserwował w dniach 5-17 maja 1684 r. (G. Sp öre r: Ueber die... (1889) s. 320), natomiast z przypisu Wolfa wynika, że: 9, 11, 14 i 17 maja 1684 r. (przypis bibliograficzny nr 150, R. Wolf: Histoire et Mémoires de l'Académie royale des Sciences. Depuis son établissement en 1666 jusqu'à 1699. Vol. 1-11., „Mittheilungen über die Sonnenflecken” z. 11: 1860 czerwiec s. 31 ).

${ }^{82} \mathrm{Ph}$. de La Hire: Observations d'une tache qui a paru sur le Disque du Soleil vers la fin $d u$ mois d'Avril et au commencement de May de cette anneé 1686, faites à l'Observatoire, „Memoires de l'Académie Royale des Sciences" t. 10: 1730 s. 707-708; wydanie paryskie, zawierające zbiór achiwalnych artykułów z czasopisma. Ta sama relacja w: J. La Lan d e: Second mémoire sur les taches du Soleil, contenant diverses observations de taches, Avec les positions qui en résultent, et la confirmation des résultats précédens, „Memoires de mathématique et de physique tirés des registres de l'Académie Royale des Sciences" t. 80: 1778 s. 402; wyd. paryskie, numer tomu to numer kolejnego rocznika dodatku do „Histoire”, którego wydawca nie zamieszczał. 
Liczba plam widocznych w czasie Minimum Maundera powiększa się natomiast, jeżeli uwzględnić zjawiska dostrzeżone przez Picarda w roku $1661^{83}$ i przez Cassiniego w roku 1680, inne widoczne jesienią 1686 r., a także gdy dodać plamy, a pewnie raczej grupy plam, obserwowane przez Heweliusza w roku 1652 a potem w latach 1653-1654, 1657 i 1660-1661 ${ }^{84}$. Część z tych zapisów dotyczy obserwowania tej samej grupy podczas kolejnych rotacji słonecznych. Identyfikację powracających plam umożliwia np. komentarz zamieszczony w katalogu Heweliusza, a dotyczący tej samej struktury widocznej przez 6 obrotów Słońca wokół osi ${ }^{85}$, czyli od końca 1659 do połowy roku 1660.

Kilka innych plam, dostrzeżonych wyłącznie przez Kircha w roku $1687^{86}$, jak również wzmianki o trzech plamach zawarte w jego korespondencji ${ }^{87}$, które przypuszczalnie widoczne były w latach ostatniej dekady wieku siedemnastego, zwiększają do ponad 60 liczbę plam, z których wiele, jeśli nie wszystkie, były grupami zawierającymi mniejsze cienie. Z zestawienia Spörera wynika, że zjawiska te były częstsze w schyłkowej fazie Minimum, czyli po roku 1700. Opisy wcześniejsze zajęły mu w jego katalogu nieco więcej niż jedną, zaś późniejsze trzy strony ${ }^{88}$. Wiadomo też, że widywano wtedy kilka plam na tarczy słonecznej w tym samym czasie.

Picard pierwszą obserwację Słońca wykonał już w roku $1645^{89}$, ale plamy dostrzegł dopiero w latach 1660-1661 ${ }^{90}$, a kolejne w: 1671 (13 sierpnia $^{91}$ ), $1672^{92}$ i 1674 r. $^{93}$. Rysunki plam, które wykonał na przełomie lipca i sierpnia 1676 r. wydają się potwierdzać, że zjawiska te były olbrzymie, o czym można wnioskować na

${ }^{83}$ Plamę obserwował w dniach 13-14 sierpnia; J.M. Va que ro, M. Vá zquez: The Sun Recorded Through History: Scientific Data Extracted from Historical Documents, Berlin 2009, s. 129.

${ }^{84} \mathrm{~J}$. Heweliu sz: Machina..., ks. III, s. 1-30.

${ }^{85}$ Tamże, s. 9. Boyle obserwowałby zatem tę samą plamę także podczas siódmej rotacji; R. Boyle: dz. cyt. s. 2216-2217.

${ }^{86}$ H.E. Land sberg: Variable Solar Emissions, the "Maunder Minimum" and Climatic Temperature Fluctuations, „Archiv für Meteorologie Geophysik und Bioklimatologie” t. 28: 1980 seria B s. 184.

87 G. Kirch: Die Korrespondenz des Astronomen und Kalendermachers Gottfried Kirch (1639-1710), red. K.D. Herbst, Jena 2006, t. II, s. 259; list z numerem 594; s. 409-410, list z numerem 745 .

${ }^{88}$ G. Spörer: Ueber die... (1889) s. 319-324.

${ }^{89}$ J.C. Ribes, E. N e sme-Ribes: The solar... s. 549-550.

${ }^{90}$ Przypuszczalnie jedna z tych plam została przez Ribesów skatalogowana na rysunku jako widoczna w 1662 r.; tamże, s. 556.

${ }^{91}$ G. Pi c ol et: La correspondence de Jean Picard avec Johann Hevelius (1671-1679). Edition et traduction française, „Revue d'Histoire des Sciences” t. 31: 1978 s. 21.

${ }^{92} \mathrm{~J}$. P i ca rd: Voyage d'Uranibourg, ou observations astronomiques faites en Dannemarck. Article premier, „Memoires de l'Academie Royale des Sciences” t. 7: 1729 cz. I s. 195; tom zbiorczego wydania artykułów z lat 1666-1669; P.C. Le Monnier: dz. cyt. s. 23-24.

${ }^{93}$ Tamże, s. 85-86. 
podstawie wielkości krzywizny dysku słonecznego na ilustracji. Potem obserwował jeszcze przez trzy kolejne dni jedną plamę w 1677 r. ${ }^{94}$, która została niewłaściwie opisana na diagramie Ribesów (miały to być trzy plamy, a nie trzy dni obserwacyjne) i była to ostatnia, jaką zaobserwował.

Olbrzymie były plamy dostrzeżone w roku 1671 przez Cassiniego, który wykonał bardzo dokładne rysunki ewolucji struktury grupy w kolejnych dniach oraz pomiary jej wielkości kątowej. W tym samym roku w „Philosophical Transactions” ukazały się trzy artykuły, z których dwa dotyczą wyłącznie spostrzeżeń tego astronoma oraz tekst poświęcony obserwacjom wykonanym przez Boyle’a jedenaście lat wcześniej, a który również wzmiankuje obserwacje Włocha ${ }^{95}$. Plama, co zostało ustalone przez Cassiniego, miała długość 75", czyli mniej więcej tyle, co średnica innej, widocznej jeszcze przed początkiem Minimum w maju 1644 r., a opisanej przez Heweliusza. Co do wielkości plamy z rysunku, jaki zamieścił Heweliusz w dodatku do Selenographia można by jednak mieć wątpliwości czy nie została zawyżona, bo badacz nie stosował mikrometru ${ }^{96}$. Szacunki wielkości plam słonecznych poczynione przez Gdańszczanina i wyrażone jako ułamek średnicy tarczy gwiazdy, a nie w sekundach łuku, znaleźć można jedynie w Cometographia ${ }^{97}$ i te raczej na pewno nie wymagały zastosowania takiego przyrządu.

Tabela 1. Daty obserwacji plam dostrzeżonych przez Picarda i de La Hire'a, skatalogowane przez Le Monniera ${ }^{98}$. W tym samym dziele zamieszczono rysunki plam widocznych 29 i 30 czerwca, w dniach 1-4 lipca 1676 r. (plamy przy brzegu tarczy słonecznej), których jednak nie ma w katalogu w tej samej książce. W zestawieniu Le Monniera nie ma również plam, które dostrzegł np. Cassini: 9, 14 i 17 maja 1684 r. ${ }^{99}$. Daty wg kalendarza gregoriańskiego.

\begin{tabular}{|l|l|}
\hline Rok & Data dzienna obserwacji plam \\
\hline 1672 & $12,14,20$ i 22 listopada \\
\hline 1674 & 29,30 i 31 sierpnia \\
\hline 1676 & $\begin{array}{l}26,27 \text { i } 28 \text { czerwca, } 1,9,11,13,14 \text { i } 30 \text { października, } 1,19,21,22,23,24, \\
25,27,28,29 \text { i } 30 \text { listopada, } 15,16,18,27 \text { i } 29 \text { grudnia }\end{array}$ \\
\hline
\end{tabular}

${ }^{94}$ W 1677 r. Picard pierwszą plamę dostrzegł 10 marca, a kolejną obserwował 10, 11 i 12 kwietnia; tamże, s. 233-234.

${ }^{95}$ R. Boyle: dz. cyt. s. 2216-2217; G.D. Cassini: New Observations... s. 2250-2253; G.D. Cassini: The Observations... s. 3020-3024.

96 J.A. E ddy, P.A. Gilm an, D.E. Trotter: Solar rotation during the Maunder Minimum, „Solar Physics” t. 46: 1976 s. 10. Według autorów Heweliusz mógł zmienić proporcje między wielkością tarczy słonecznej, a wielkością rysowanych plam.

${ }^{97}$ J. Hew eli us z: Cometographia, Gdańsk 1668, s. 401.

${ }^{98}$ P.C. Le Monnier: dz. cyt. s. 23-24 i 85-328.

${ }^{99}$ Przypis bibliograficzny nr 150, R. Wolf, Histoire et Mémoires... en 1666 jusqu'à 1699... s. 31. Daty te nie są również dokładnie cytowane przez Maundera, który wymienił jedynie miesiąc, bez dat dziennych. 


\begin{tabular}{|l|l|}
\hline 1677 & 10 marca, 10, 11 i 12 kwietnia \\
\hline 1684 & $\begin{array}{l}\text { 5, 6, 7 i } 8 \text { maja, 11, 12, 13, 27, 28, } 29 \text { i } 30 \text { czerwca, 1, 3, 4, 5, 6, 7, 8, 9, 25, } \\
26 \text { i } 28 \text { lipca }\end{array}$ \\
\hline
\end{tabular}

Plamy opisane przez Cassiniego dostrzegł 13 sierpnia także Picard ${ }^{100}$, podczas rejsu po Morzu Północnym ${ }^{101}$. Ponadto zjawisko to obserwował również Heweliusz ${ }^{102}$, którego zainteresowanie tematem po szczycie liczby plam w 1660 r., czyli po 19 latach obserwacji powierzchni Słońca, bardzo znacznie osłabło.

Rok później, w październiku i listopadzie 1672 r., grupę plam na Słońcu obserwował Bion ${ }^{103}$. Rysunki i raporty ze swoich obserwacji zamieścił w książce L'usage des globes célestes et terrestres, et des sphéres suivant les différens systemes du monde. Ten opis pozostał jednak nieznanym dla Spörera i Maundera, a przypomniany został dopiero w 2006 r. w publikacji Ricardo Casasa.

W roku 1671, co wiadomo na podstawie opublikowanej korespondencji, powierzchnię Słońca zaczął obserwować Flamsteed. Pierwszą swoją plamę zaobserwował dopiero 26 lipca 1676 kalendarza juliańskiego ${ }^{104}$ i potem obserwował plamy dosyć często do końca roku ${ }^{105}$. Również i te obserwacje uprzedził o ponad miesiąc Picard, który dostrzegł je na przełomie czerwca i lipca (tabela 1). Być może zainteresowanie Flamsteeda, które datuje się na $1671 \mathrm{r}^{106}$, pojawiło się bezpośrednio po lekturze wydanych wówczas W „Philosophical Transactions” artykułów o nowych obserwacjach plam ${ }^{107}$.

Cassini kolejne plamy zaobserwował potem dopiero 30 października, a następnie w listopadzie, podobnie jak Flamsteed. Anglik z końcem roku przestał zauważać te zjawiska, zaś Cassini badania kontynuował. Przed 1684 r. Włoch plamy obserwował jeszcze w latach 1678 (rysunek 3) i 1680. Natomiast w podrozdziale Historia coelestis Britannica, który powinien zawierać raporty Flamsteeda z lat 1676-1689, nie ma już żadnych późniejszych relacji niż o plamach dostrzeżonych w grudniu roku 1676.

Następną plamę Flamsteed obserwował dopiero na przełomie kwietnia i maja 1684 r. kalendarza juliańskiego, co opisał w „Philosophical Transactions” ${ }^{108}$. Plama ta była dosyć duża, o wielkości około 40" i kształcie kwadratu. W tym samym

${ }^{100}$ G.D. Cassini: New Observations... s. 2253.

${ }^{101}$ J. Picard: Voyage d'Uranibourg... s. 195.

102 J. Heweliusz: Machina..., ks. III, s. 21.

${ }^{103}$ R. Casas, J. M. Va que ro, M. Váz que z: Solar rotation in the $17^{\text {th }}$ century, „Solar Physics” t. 234: 2006 s. 384.

${ }^{104}$ J. Flam steed, E. Halley: An Extract... s. 687-688.

${ }^{105} \mathrm{~J}$. Flam stee d: Historia coelestis..., ks. I, s. 361-366.

${ }^{106}$ Tenże: The correspondence..., t. 1, s. 116, list 72; s. 124, list 81; s. 130, list 84.

${ }^{107}$ R. B oyle: dz. cyt. s. 2216-2217; G.D. Cassini: New Observations... s. 2250-2253; G.D. Cassini: The Observations... s. 3020-3024.

${ }^{108} \mathrm{~J}$. Flam stee d: An account of a Spot seen in the Sun from the 25th. of April to the 8th. of May instant, with the line of its Course predicted, if it make a second Return, by I.F. Astron. Reg., „Philosophical Transactions” t. 14: 1684 s. 535-536. 
czasie to samo zjawisko obserwowano w Obserwatorium Paryskim, wyznaczając tor podobnie nachylony do horyzontalnej średnicy Słońca, ale zarówno cień, jak i półcień plamy okazały się prawie idealnie koliste ${ }^{109}$. W tych samych dniach niezależne obserwacje wykonał także de La Hire ${ }^{110}$, który zaobserwował plamę o jeszcze innym kształcie cienia, z wyraźnie nachyloną najdłuższą osią, która wydaje się wskazywać inną pozycję na dysku słonecznym. Z zestawienia obserwacji pozycyjnych plamy, które wykonał, wynika, że widoczna była po przeciwnej stronie tarczy słonecznej niż ta, którą opisał Flamsteed.

Plamy widocznej w 1695 r. Flamsteed nie dostrzegł, ale z zapisów katalogu Historia coelestis Britannica wiadomo, że wykonywał już wówczas obserwacje metodą tranzytów. Mógł zatem nie zauważyć cienia, którego wielkość nie przekroczyła progu widoczności w jego lunecie. 30 czerwca zauważył podczas takich obserwacji aż trzy plamy, ale zapisał czas kontaktu tylko jednej ${ }^{111}$. Z listów napisanych przez Flamsteeda i datowanych na $3^{112}$ i $19^{113}$ maja 1698 r. wiadomo, że od 1684 r. nie zaobserwował żadnej, mimo że były wtedy widywane, o czym wiedział, bo potwierdza to treść tej korespondencji.

Systematyczny program pomiarów średnicy kątowej Słońca wykonywany był przez Picarda stale od $1666 \mathrm{r}^{114}$. Pierwsze plamy w trakcie wykonywania obserwacji astrometrycznych dostrzegł dopiero w $1672 \mathrm{r}^{115}$, choć już rok wcześniej obserwował zjawisko z pokładu okrętu ${ }^{116}$. Mała średnica obrazu dysku słonecznego uzyskiwana poprzez lunetę stosowaną do pomiarów średnicy kątowej Słońca ${ }^{117}$ umożliwiała mu dostrzeżenie jedynie plam największych, być może pojawiających się w bardziej ograniczonym zakresie szerokości heliograficznych niż wszystkie. W ten sposób wyniki tych obserwacji mogłyby potwierdzić okresy, gdy zjawiska te pojawiały się liczniej.

Średnica tak dużej plamy, jak ta obserwowana w drugiej dekadzie maja $1644 \mathrm{r}$. przez Heweliusza, na obrazie rzutowanym przez teleskop Picarda byłaby mniejsza niż milimetr. Stąd wniosek, że astronom używał większej lunety jedynie wtedy, gdy plamę zauważył wcześniej podczas rutynowych obserwacji astrometrycznych wykonywanych w czasie lokalnego południa. Konkluzję taką wydają się potwierdzać

109 [Tekst bez nazwiska autora]: Description d'une tache qui a paru dans le Soleil ce mois de May dernier 1684, „Journal des sçavans” t. 12: 1684 nr 15 197-201, wyd. amsterdamskie z 1709 r.; w wydaniu paryskim s. 177-180.

${ }^{110}$ P.C. Le Monnier: dz. cyt. plansza bez paginacji z rysunkami na końcu książki.

${ }^{111}$ J. Fla ms tee d: Historia coelestis..., ks. II, s. 462.

${ }^{112}$ Tenże: The correspondence..., t. 2, s. 675-676, list o numerze 745.

${ }^{113}$ Tamże, s. 678, list o numerze 747.

${ }^{114}$ E. Ribes, J.C. Ribes, R. Barthalot, dz.cyt. s. 52.

${ }^{115}$ P.C. Le Monnier: dz. cyt. s. 23-24.

${ }^{116}$ G.D. Cassini : New Observations... s. 2253.

${ }^{117}$ E. Ribes, J.C. Ribes, R. Barthalot: dz. cyt. s. 52. 
zapisy katalogu Le Monniera ${ }^{118}$. Wiele mniejszych grup powinno wtedy pozostać niezauważonych dla obserwatora. Także de La Hire, który po 1682 r. kontynuował program obserwacyjny realizowany wcześniej przez Picarda i mierzył średnicę horyzontalną Słońca metodą kontaktów, posługiwał się przypuszczalnie obrazem dziennej gwiazdy podobnych rozmiarów, gdyż większy nie pozwalałby mu właściwie zorientować teleskopu, a wtedy wyznaczałby momenty pojawienia się i zniknięcia dowolnych punktów tarczy, zamiast wyznaczających średnicę horyzontalną.

Według opracowania Ribesów w 1676 r. Picard dostrzegł 6 plam, obserwując Słońce przez: 9, 10, 13, 21, 4, 5, 14, 5, 18, 10, 4 i 15 dni w kolejnych miesiącach ${ }^{119}$. Zbliżoną łączną liczbę dni w czasie całego roku, gdy wykonywano pomiary astrometryczne, znalazłem analizując zapisy katalogu Le Monniera ${ }^{120}$. W 1677 r., jak można wnioskować z histogramu zamieszczonego w publikacji Ribesów ${ }^{121}$, obserwował tylko przez 58 dni i zaobserwował, co wiadomo z osiemnastowiecznego opracowania, dwie plamy. Po zajrzeniu do dzieła Le Monniera okazuje się, że ten skatalogował jednak jedynie 48 dni obserwacyjnych w czasie całego roku, z tego 39 dni przypadło na obserwacje Słońca ${ }^{122}$. W 1678 r. Picard nie zauważył żadnej plamy, ale spoglądał w niebo znacznie rzadziej. Podczas 7 dni obserwacyjnych dostrzegł je wtedy Cassini ${ }^{123}$. Potem, w latach 1682 i 1683 w Paryżu nie widziano ani jednej ${ }^{124}$. Natomiast w 1684 r. dostrzeżono tam według Ribesów już trzynaście plam ${ }^{125}$, co jednak nie znajduje potwierdzenia w opracowaniu Le Monniera, nawet jeżeli próbować interpretować zjawiska zaobserwowane w tym roku przez Cassiniego jako rożne od dostrzeżonych przez de La Hire’a, czy uwzględniać drugą plamę widoczną na Słońcu w tym samym czasie, co miało miejsce 11 czerwca $^{126}$.

Wiele oryginalnych opisów plam znalazło się w ówczesnych czasopismach naukowych - „Journal des sçavans”, „Histoire de l'Academie Royale des Sciences” oraz

${ }^{118}$ Pomiar wysokości Słońca w czasie lokalnego południa. Wg katalogu Le Monniera plamy zostały zaobserwowane właśnie wtedy; P.C. Le Monnier: dz. cyt. s. 23-24 i 85-328.

${ }^{119}$ Liczby obserwacji w poszczególnych latach zostały ustalone na podstawie histogramu w publikacji J.C. Ribesa i E. Nesme-Ribes i mogą się nieco różnić od oryginalnych; J.C. Ribes, E. Nesme-Ribes: The solar... s. 556.

${ }^{120}$ P.C. Le Monnier: dz. cyt. s. 206-228.

${ }^{121}$ J.C. Ribes, E. Nesme-Ribes: The solar... s. 556.

${ }^{122}$ P.C. Le Monnier: dz. cyt. s. 229-237.

${ }^{123}$ Przypis bibliograficzny nr 150, R. Wolf: Histoire et Mémoires... en 1666 jusqu'à 1699... s. 31.

${ }^{124}$ Plamy w latach 1682-1683 przez jeden dzień obserwował Eimmart, a później także w czerwcu 1684 oraz w 1703; na podstawie katalogu Hoyta i Schattena: ftp.ngdc.noaa.gov/ STP/SOLAR_DATA/SUNSPOT_NUMBERS/GROUP_SUNSPOT_NUMBERS/alldata. Strona obecnie niedostępna.

${ }^{125}$ Patrz: tabela 2, zawierająca łączne liczby plam dostrzeżonych tam w kolejnych latach, ustalone na podstawie książki Le Monniera.

${ }^{126}$ Z porównania czasów kontaktów dwu dużych plam wynika, że były odległe o 2'; P.C. Le Monnier: dz. cyt. s. 319. 
„Memoires de mathematique et de physique tirés des registres de l'Academie Royale des Sciences”, które od 1699 r. ukazywały się jako forma dodatku do „Historii”. Do 1703 r. liczba opracowań podobnych obserwacji z każdym kolejnym rocznikiem łączonego wydawnictwa szybko wzrastała, a były to opisy zamieszczane głównie przez Cassiniego i de La Hire'a ${ }^{127}$. Po 1705 r. ukazywał się prawie co roku jeden artykuł w „Histoire”, po czym w 1721 r. plamy słoneczne zniknęły zupełnie z tytułów publikacji na okres co najmniej jednej dekady.
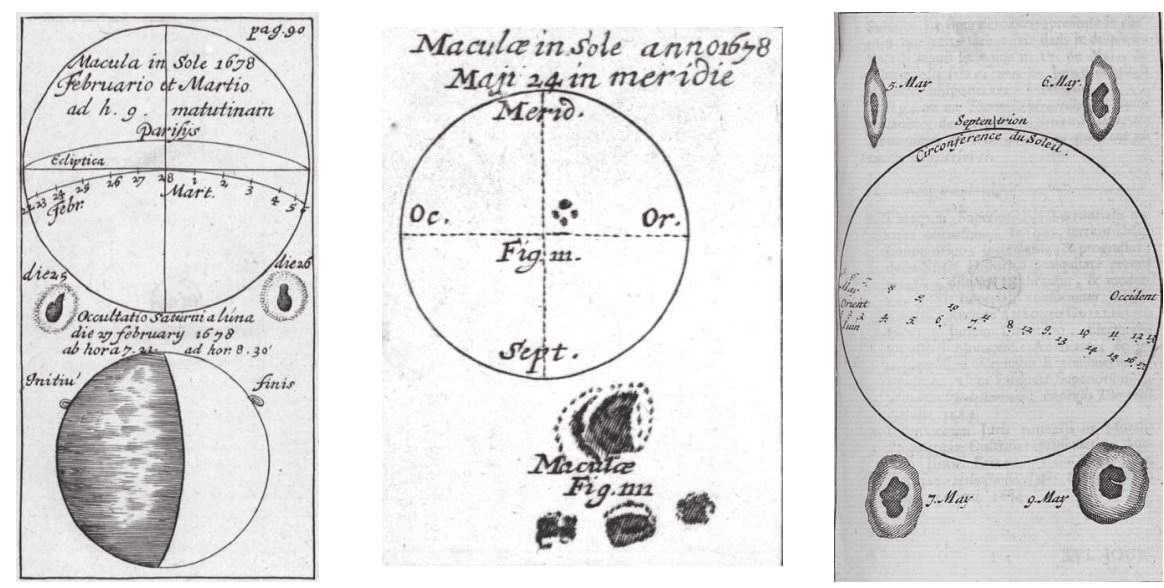

Rysunek 3. Ilustracje plam okresu Minimum skatalogowanych przez Spörera. Na dwu rysunkach z lewej strony znalazły się struktury obserwowane przez Cassiniego w lutym i marcu ${ }^{128}$ oraz w maju ${ }^{129} 1678 \mathrm{r}$. Fragment środkowego reprodukowany jest także w jednym z przypisów bibliograficznych Wolfa ${ }^{130}$. Po prawej tor plamy obserwowanej przypuszczalnie przez Cassiniego w maju 1684 r. wraz ze szczegółami zmian wyglądu zjawiska w wybranych dniach ${ }^{131}$. W tym samym czasie przemieszczającą się na tarczy plamę obserwował Flamsteed i podobny rysunek toru zamieścił w „Philosophical Transactions” ${ }^{132}$. Za zgodą Biblioteki Uniwersytetu Warszawskiego.

${ }^{127}$ W 1699 r. nie ukazał się żaden tekst o plamach, w 1700 r. dwa (w tym jeden w „Memoires”), w 1701 r. cztery (w tym trzy w „Memoires”), w 1702 r. trzy, w 1703 r. jedenaście (wszystkie autorstwa Cassiniego i de La Hire'a), w 1704 r. siedem (de La Hire'a i Maraldiego) oraz tekst zawierający opis obserwacji wykonanych przez Manfrediego.

${ }^{128}$ [Tekst bez nazwiska autora]: Observation d'une Nouvelle tâche dans le Soleil, „Journal des sçavans" t. 6: $1678 \mathrm{nr} 8$ s. 90-91, wyd. amsterdamskie z 1679 r.; rysunek wewnątrz nr 9, pomiędzy numerowanymi stronami 96 i 97. W wydaniu paryskim całość na stronach 88-90.

${ }^{129}$ G.D. Cas sin i: Observation de plusieurs taches et facules dans le Soleil faite à l'Observatoire Royal par M. Cassini, ,Journal des sçavans” t. 6: $1678 \mathrm{nr} 21$ s. 260-262, wyd. amsterdamskie z 1679 r.; rysunek między stronami 246 i 247; wyd. paryskie 1678 tekst na s. 248, zaś rysunek na s. 240.

${ }^{130}$ R. Wolf: Macula in Sole anno 1678 Maji 24 in meridie, „Astronomische Mittheilungen” z. 33: 1873 sierpień s. 107-108.

${ }^{131}$ [Tekst bez nazwiska autora]: Description d'une tache qui a paru dans le Soleil ce mois de May dernier 1684, „Journal des sçavans” t. 12: 1684 nr 15 s. 197-201; wyd. amsterdamskie z 1709 r., w wydaniu paryskim s. 177-180.

${ }^{132} \mathrm{~J}$. Fla msteed: An account... s. 535-536. 
Temat plam wyraźnie uszedł uwadze innego wydawnictwa - „Nouvelles de la république des lettres”, ukazującego się od 1684 r. Artykuł poświęcony badaniom astronomicznym, w którym plamy są opisane przeglądowo i nie zawiera żadnych wyników bieżących obserwacji, ukazał się tam dopiero w lutym 1689 r. ${ }^{133}$. Wzmiankuje m.in. 26 rysunków wykonanych przez Heweliusza jeszcze w latach czterdziestych. W czasopiśmie tym nie też żadnych jego publikacji.

Natomiast aż trzynaście artykułów Heweliusza zostało zamieszczonych w ukazujących się od 1682 r. lipskich „Acta Eruditorum”, ale żaden nie dotyczy obserwacji plam słonecznych. Spörer wymienił to czasopismo jako źródłowe dla wykonanych przez Kircha, wzmiankując plamę widoczną w roku $1684^{134}$.

Całkiem dużo o obserwacjach powierzchni dziennej gwiazdy wiadomo na podstawie zawartości korespondencji naukowej, jaką prowadzili obserwatorzy, między innymi Kirch. Badacz ten wysłał np. list do Heweliusza z opisem obserwacji plamy w maju 1684 r. ${ }^{135}$. Wcześniej, bo 18 sierpnia 1671 r., list z wiadomością o innej plamie na Słońcu napisał do Heweliusza Picard, na co ten odpisał 28 sierpnia, że w Lipsku widoczna była od $2^{136}$ do 9 sierpnia ${ }^{137}$.

Przed 1665 r., czyli przed ukazaniem się pierwszego numeru „Philosophical Transactions” w Anglii oraz „Journal des sçavans” we Francji, listy przesyłane między ówczesnymi astronomami pozostawały głównym źródłem informacji o dokonaniach innych. Zdarzało się, jak stało się to z listami Galileusza, że były potem publikowane w formie książkowej.

Tabela 2. Roczne liczby plam słonecznych dostrzeżonych w Obserwatorium Paryskim; na podstawie publikacji Ribesów z 1993 r. ${ }^{138}$. W ich zestawieniu brak jednak wielkiej plamy z roku 1674 dostrzeżonej przez Picarda w Montpellier ${ }^{139}$, jak również plam z 1680 r., które obserwował Cassini. Uwzględnione zostały natomiast inne obserwacje Włocha, wykonane w $1678 \mathrm{r}$.

W prawej kolumnie liczby plam, o jakich można wnioskować na podstawie katalogu Le Monniera ${ }^{140}$. Zwraca uwagę rozbieżność w opisie 1684 r. Wiadomo, że w tym

${ }^{133}$ J. Luyts: Philosophiae Professoris Astronomica Institutio, in qua Doctrina Sphaerica atque Theorica, intermixto usu Sphaerae Coelestis, et varius Chronologicis, pertractantur. Adjunctae sunt in illustrationem Argumenti pluribus in locis Figurae aeneae, „Nouvelles de la république des lettres" t. 3: 1689 maj s. 127, wzmianka o rycinach Heweliusza na s. 140; wydanie amsterdamskie $\mathrm{z}$ tego samego roku.

${ }^{134}$ G. Spörer: Ueber die... (1889) s. 320.

${ }^{135}$ G. Kirc h: dz. cyt., t. I, s. 298-299; list z numerem 267.

${ }^{136}$ Kalendarza juliańskiego.

${ }^{137}$ G. Pic olet: La correspondence... s. 21 i 24.

${ }^{138}$ J.C. Ribes, E. Nesme-Ribes: The solar... s. 556.

${ }^{139}$ D.V. H oyt, K.H. Sch atten: Group sunspot numbers: a new solar activity reconstruction, „Solar Physics” t. 179: 1998 s. 207.

${ }^{140}$ P.C. Le Monnier: dz. cyt. s. 23-24 i 85-328. 
czasie plamy obserwowali również inni obserwatorzy: między 15 a 21 kwietnia 1684 r. (daty wg kalendarza juliańskiego; Kirch) ${ }^{141}, 27$ czerwca 1684 r. $^{142}$ (data wg kalendarza gregoriańskiego; Cassini), a także 27 lipca 1684 r. (data wg kalendarza gregoriańskiego; Kirch) ${ }^{143}$. Obserwacje te zwiększają łączną liczbę dostrzeżonych w 1684 r. plam z pięciu skatalogowanych przez Le Monniera (lub sześciu, bo 11 czerwca de La Hire dostrzegł dwie różne plamy) do 8 (lub 9).

\begin{tabular}{|l|c|c|}
\hline Rok & Liczba zaobserwowanych plam wg Ribesów & Katalog Le Monniera \\
\hline 1662 & $1^{144}$ & - \\
\hline 1671 & 1 & 2 \\
\hline 1672 & 2 & 2 \\
\hline 1674 & - & 6 \\
\hline 1676 & 6 & 2 \\
\hline 1677 & 4 & - \\
\hline 1678 & $6^{145}$ & 5 \\
\hline 1684 & 13 & - \\
\hline 1685 & $1^{146}$ & - \\
\hline 1686 & $6^{147}$ & - \\
\hline 1688 & $9^{148}$ & - \\
\hline 1689 & $2^{149}$ & - \\
\hline 1695 & 1 & \\
\hline
\end{tabular}

${ }^{141} \mathrm{~J}$. Flam stee d: The correspondence..., t. 2, s. 314-315, list numer 574. „On April 15 th at 10.30 a.m. I saw a spot on the sun which was still 1 digit away from the sun's centre at 5.30 p.m.; on the 17 th at 6 p.m. $2 \frac{1 / 2}{2}$ digits; but from the sun's limb on 19 th at 6 p.m. $1 \frac{1 / 2}{2}$ digits, and on 21 April at 7 a.m. $1 / 3$ digit".

${ }_{142}$ Przypis bibliograficzny nr 150, R. Wolf: Histoire et Mémoires... en 1666 jusqu'à 1699... s. 31. De La Hire obserwował w tym dniu Słońce, ale wschodzącej wówczas plamy nie zauważył; P.C. Le Monnier: dz. cyt. s. 323.

${ }^{143}$ H.E. Land sberg: dz. cyt. s. 184.

${ }^{144}$ Picard obserwował plamę w roku 1661; J.M. Va que ro, M. Vázqu ez: The Sun... s. 129.

${ }^{145}$ Ilustracje dwu grup plam prezentowane są na rysunku 4. Cassini plamy obserwował także pod koniec maja, co Spörer ustalił na podstawie „Memoires de l'Académie Royale des Sciences" t. 10: 1730 s. 604-605, wyd. paryskie. Była to jednak ta sama grupa, co dostrzeżona 24 maja i wówczas w całym 1678 r. byłoby widocznych jedynie pięć plam.

${ }^{146}$ Opisu tej obserwacji nie ma w katalogu Le Monniera, którego zapisy kończą się 30 grudnia 1685 r. Nie jest również wzmiankowana w przypisach czasopisma Wolfa.

${ }^{147}$ De La Hire obserwował jedną plamę przez pięć dni na przełomie kwietnia i maja, po czym kolejna była widoczna w dniach 22-26 września. W dwuzdaniowym opisie jesiennych obserwacji wzmiankowane są jedynie plamy, bez podania liczby; Ph. de La Hire: Observations d'une tache...de May de cette anneé 1686... s. 707-708 (ten sam opis został zamieszczony wcześniej w „Journal des sçavans": Ph. de La Hire: Observations d'une tache qui a paru sur le Disque du Soleil vers la fin du mois d'Avril et au commencement de May de cette année 1686, faites á l'observatoire. Par M. de la Hire. Prof. R. et de l'Academie des Sciences, „Journal des sçavans” 1686 s. 250, wyd. paryskie bez numeracji bieżących tomów); G.D. Cassini: Découverte de la lumiere celeste qui paroist dans le zodiaque, „Memoires de l'Academie Royale des Sciences” 


\section{Duże plamy dostrzeżone w głównej fazie minimum}

W okresie Minimum Maundera wielokrotnie obserwowano plamy, które mogły być widoczne bez zastosowania przyrządu o powiększeniu kątowym ${ }^{150}$. Dużą plamą była już ta, którą Boyle zauważył w maju $1660 \mathrm{r}^{151}$. Wiadomo, że zanim kształt cienia wypełnił się do kwadratowego, rozciągała się na około 1/40 średnicy tarczy słonecznej. Bez lunety została dostrzeżona potem 22 maja w Korei ${ }^{152}$, czyli trzy dni wcześniej niż Boyle zauważył zjawisko ponownie po ponad dwutygodniowej przerwie. Tej samej plamie przyglądał się podczas wcześniejszej rotacji także Heweliusz w Gdańsku153.

Olbrzymią grupę, która 12 sierpnia 1671 r. rozciągała się na 30" do 75", wzmiankowaną już w niniejszej publikacji, obserwował w drugiej dekadzie miesiąca Cassini i opisał w „Philosophical Transactions”154. Dostrzegł tę również Heweliusz, choć w swoim katalogu napisał jedynie o pojedynczej plamie ${ }^{155}$. Długość plamy z $1671 \mathrm{r}$. dorównywała średnicy największej z widocznych w latach 1642-1644 i skatalogowanej w Selenographia, o kształcie kolistym. 15 sierpnia Włoch w tej samej grupie dostrzegł siedem plam, ale na ilustracji można się doliczyć aż szesnastu.

Również w późniejszych latach, podczas głównej fazy Minimum Maundera przed 1700 r., na tarczy słonecznej pojawiały się duże plamy. Wzmiankuje taką

t. 8: 1730 s. 185, wyd. paryskie. Publikacja Spörera wzmiankuje tylko dwa okresy widoczności plam w czasie całego roku; G. Spörer: Ueber die... (1889) s. 320. Plama widoczna 12 maja 1686 r. wzmiankowana jest w: G.D. Cassini: Observation des taches qui ont paru dans le Soleil le mois de Mai et de Juin de 1688. avec une Methode nouvelle de determiner avec justesse la revolution $d u$ Soleil autour de Son axe, „Journal des sçavans” 1688 s. 167-171, wyd. paryskie bez numeracji bieżących tomów.

${ }^{148}$ Plamy obserwowano: 5 maja (J. La Lande: Second mémoire... s. 402); 6 i 13 maja (G.D. Cassini: De la Tache du Soleil, qui a paru le 6 Mai 1702. Par M. Cassini le fils, „Memoires de mathématique et de physique tirés des registres de l'Académie Royale des Sciences" t. 4:1702, s. 133 wyd. paryskie, numer tomu to jedynie numer kolejnego rocznika dodatku do "Histoire”, których wydawca nie numerował.), zaś lista Spörera wymienia jedynie 12 maja (choć tytuł tekstu z tomu X „Memoires” wzmiankuje również plamy widoczne w czerwcu), a także: 30 września, 1 października, 1-3 listopada, 10 listopada, 14 listopada (przypis nr 150 Wolfa; R. Wolf: Histoire et Mémoires... en 1666 jusqu'à 1699... s. 30-31).

149 Plamy obserwowane były w dniach: 19-22 lipca oraz 27 i 29 października 1689 r.; 29 października widocznych było jednak aż 6 plam; przypis 7 w R. Wolf: Aug. Vagetius, De maculisin Sole visis. Wittembergae 1693, „Mittheilungen über die Sonnenflecken” z. 3: 1857 marzec s. 46-47.

${ }^{150}$ Najmniejsza plama, jaką dostrzeżono bez lunety, miała średnicę kątową równą 21"; B.E. Schaefer: dz. cyt. s. 40.

${ }^{151}$ R. B oyle: dz. cyt. s. 2216-2217.

${ }^{152}$ A.D. Wittmann, Z.T. Xu: dz. cyt. s. 93.

${ }^{153}$ J. Heweliusz: Machina..., ks. III, s. 9.

${ }^{154}$ G.D. Cas sini: New Observations... s. 2250-2253.

155 J. Heweliu sz: Machina..., ks. III, s. 21. 
Picard w $1674 \mathrm{r}^{156}$, ale także Flamsteed, który pierwszą grupę dostrzegł dopiero po pięciu latach obserwacji Słońca w 1676 r. i opisał w „Philosophical Transactions”. Z jego listu wiadomo ${ }^{157}$, że osiągnęła wielkość 50 " na 80 ". W tym samym numerze czasopisma opis tych samych plam zamieścił Cassini wraz z ilustracją zmian kształtu grupy w wybranych dniach.

W maju 1680 r. dużą plamę, co wzmiankuje źródłowy opis, ponownie zaobserwował Cassini ${ }^{158}$, jak również Kirch $^{159}$. Duża była także plama dostrzeżona przez Flamsteeda w roku 1684 (o „średnicy” około 40”) ${ }^{160}$, choć według innej relacji miała być mniejsza niż pół minuty kątowej ${ }^{161}$, oraz plama widoczna wcześniej w listopadzie 1676 r., co wiadomo na podstawie rysunku wykonanego przez Cassiniego i zamieszczonego $\mathrm{w}$ „Journal des sçavans” ${ }^{162}$.

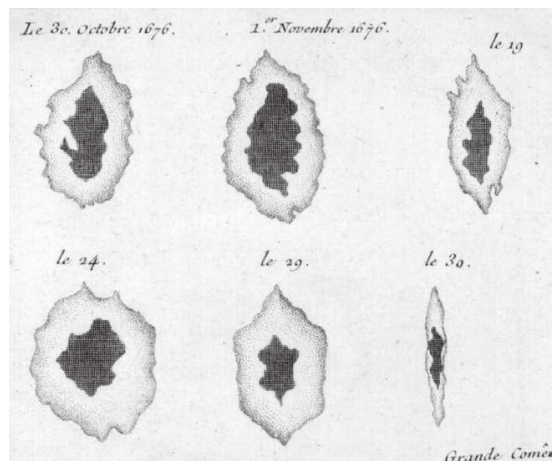

Rysunek 4. Plamy widoczne w październiku i listopadzie 1676 r. Fragment większego zestawienia rysunków wykonanych przez Picarda, zamieszczonego później w opracowaniu Le Monniera z połowy XVIII w. ${ }^{163}$. Gian Domenico Cassini obserwował te same plamy i opublikował, nieznacznie różniące się kształtem od powyższych, własne wersje ilustracji w „Journal des sçavans" ${ }^{164}$. Widoczny efekt skrócenia perspektywicznego przy zbliżaniu się cienia do brzegu dysku słonecznego. Za zgodą Biblioteki Uniwersytetu Warszawskiego.

${ }^{156}$ P.C. Le Monnier: dz. cyt. s. 85.

${ }^{157}$ J. Fla m ste ed: The correspondence..., t. 1, s. 498-499, list o numerze 268 z 27 lipca 1676 r. napisany przez Flamsteeda do J. Moore'a.

158 [Komunikat bez tytułu i autora]: „Histoire de l'Académie Royale des Sciences” t. 1: 1733 s. 317-318.

${ }^{159}$ H.E. Land s berg: dz. cyt. s. 184.

${ }^{160} \mathrm{~J}$. Flamsteed: An account... s. 535-536.

161 [Tekst bez nazwiska autora]: Description d'une tache qui a paru dans le Soleil ce mois de May dernier 1684, „Journal des sçavans” t. 12: 1684 nr 15 s. 197-201; wyd. amsterdamskie z 1709 r., w wydaniu paryskim s. 177-180.

${ }^{162}$ G.D. C assini: Description du mouvement ou a fait une tache dans le Soleil sur la fin de Novembre dernier 1676, „Journal des sçavans” 1676 s. 239-240, wyd. paryskie bez bieżącej numeracji tomów.

${ }^{163}$ P.C. Le Monnier: dz. cyt. s. bez paginacji, tablice II i IV.

${ }^{164}$ G.D. Cassini: Suite des observations faites à l'Observatoire Royal, touchant la Tache qui a paru dans le Soleil, les mois d'Octobre, de Novembre et Decembre derniers, "Journal des sçavans" t. 5: 1677 s. 11-13, wyd. amsterdamskie; w wyd. paryskim s. 8-9. 
Duże plamy w roku 1687 wzmiankuje w końcu opracowanie Helmuta Ericha Landsberga (1906-1985), który zestawił spostrzeżenia Kircha zamieszczone w korespondencji.

Olbrzymie musiały być także trzy plamy dostrzeżone przez Flamsteeda 30 czerwca $1703 \mathrm{r}^{165}$, zważywszy na to, że wykonywał wtedy obserwacje Słońca metodą tranzytów ${ }^{166}$. Wcześniej nie zauważył innej, widocznej w 1695 r., obserwując dzienną gwiazdę podobnym sposobem 18 maja kalendarza juliańskiego ${ }^{167}$.

Rysunki dużych plam wykonane w latach 1676 i 1684 przez Picarda i de La Hire’a zostały w roku 1741 opublikowane przez Le Monniera w Histoire celeste ${ }^{168}$; patrz rysunek 4. Ponieważ zestawił on obserwacje wykonane od 1672 r. do 30 grudnia 1685 r. katalog ten nie zawiera relacji Picarda z 1671 r., jakichkolwiek wcześniejszych, czy np. opisu zjawiska widocznego w 1695 r.

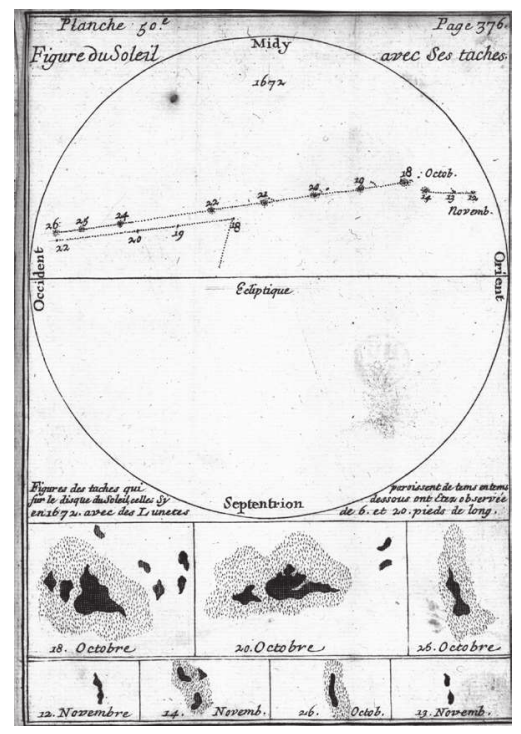

Rysunek 5. Tory i rysunki plam dostrzeżonych przez Biona w 1672 r. Przykład opisu do niedawna nieznanego badaczom okresu Minimum Maundera, a jednocześnie wykonanego najwyraźniej z małą dokładnością. Korzystając z pozycji plamy wyznaczonych w listopadzie Casas obliczył wyjątkowo powolne tempo rotacji Słońca, które musiałoby się wydłużyć do 36 dni, jeżeli obserwacje te uznać za dokładne. Natomiast wcześniej, w październiku, widoczne były równocześnie dwie grupy plam. Rysunki te, podobnie jak plam z 1671 r., potwierdzają, że zjawiska dostrzeżone w okresie Minimum Maundera to często złożone struktury, z licznymi cieniami. Rysunki te zostały zamieszczone w książce Biona ${ }^{169}$, a wykonane z użyciem lunet o długości 6 i 20 stóp. Za zgodą Biblioteki Uniwersytetu Warszawskiego.

\footnotetext{
${ }^{165} \mathrm{~J}$. Flam stee d: Historia coelestis..., ks. II, s. 462.

${ }^{166} \mathrm{~W}$ zestawieniu katalogu podał czas kontaktu tylko jednej.

${ }^{167} \mathrm{~J}$. Flam stee d: Historia coelestis..., ks. II, s. 255.

${ }^{168}$ P.C. Le Monnier: dz. cyt. s. bez paginacji, tablice II i IV.

${ }^{169}$ N. Bi on: dz. cyt. s. 376.
} 
Przykłady opisane w tym rozdziale potwierdzają, że plamy zaobserwowane w czasie Minimum Maundera osiągały duże rozmiary. Wiele, nieco mniejszych od największych, powinno pozostać nie zauważonych podczas pomiarów średnicy tarczy słonecznej wykonywanych w Paryżu przez Picarda, a potem de La Hire’a z powodu małej wielkości obrazu tarczy Słońca uzyskiwanego zresztą celowo, by ten mógł zmieścić się w polu widzenia lunety i „widełkach” mikrometru ${ }^{170}$. Niejednoznaczności wynikające z podobnych obserwacji wykonywanych np. przez Flamsteeda zostały opisane $\mathrm{w}$ rozdziale następnym.

\section{Pominięte plamy minimum Maundera}

W 1710 r. „Philosophical Transactions” zamieściły artykuł Derhama ${ }^{171}$, zawierający listę obserwacji plam, z których kilka widocznych w latach 1703 i 1706 Spörer pominął ${ }^{172}$, publikując w 1889 r. swój katalog ${ }^{173}$. Zjawiska opisane przez Anglika zostały dostrzeżone w schyłkowej fazie siedemdziesięcioletniego okresu, nazwanego później nazwiskiem Maundera.

Inne zestawienie, autorstwa Eustachego Manfrediego (1674-1739) ${ }^{174}$, mające wg D.V. Hoyta i K. Schattena pośrednio potwierdzać brak plam na tarczy słonecznej, natrafia na szereg równoczesnych obserwacji wykonanych w tych samych dniach przez innych obserwatorów, z czego wynika, że zjawiska te były jednak wówczas widoczne ${ }^{175}$. Część tych relacji to $\mathrm{w}$ rzeczywistości wyniki pomiarów średnicy

170 Sposób, w jaki Picard korzystał z mikrometru Auzouta opisano w: J.C. Ribes, E. Nesme-Ribes: The solar... s. 552-554.

${ }^{171}$ W. Derham: dz. cyt. s. 270-289.

${ }^{172}$ Tamże; pominięte zostały plamy widoczne w dniach: 11-13 kwietnia, 1 maja, 24 czerwca (Derham nie był pewien czy plamę dostrzegł, ale skatalogował), w lipcu i we wrześniu 1704 r., 7 lutego, 7 marca, 2 kwietnia, w dniach 24-25 lipca 1706 r. oraz 22 stycznia 1710 r. (daty interpretowane jako juliańskie). Maunder pominął jeszcze więcej plam w 1703 r. (do dziewięciu), zaś Spörerowi dla odmiany zdarzyło się mnożyć spostrzeżenia Derhama. Zacytował sekwencję obserwacji Anglika, którą ten wykonał w dniach 4-11 września 1706 r., dodając te same z datą zamienioną na gregoriańską, czyli 14-19 września. Tych dodatkowych dni $\mathrm{w}$ artykule Derhama nie ma.

${ }^{173}$ G. Spörer, Ueber die...(1889) s. 319-324.

${ }^{174}$ E. Manfredi: De gnomone meridiano bononiensi ad divi Petronii, Bolonia 1736.

17526 listopada 1676 (plamę wciąż obserwował Cassini; na podstawie przypisu bibliograficznego $\mathrm{nr}$ 150, R. Wolf: Histoire et Mémoires... en 1666 jusqu'à 1699... s. 31.), 8, 9 i 13 listopada 1700 (Wurzelbaur, G. Cassini), 29 marca 1701 (G. Cassini), 31 października 1701 oraz 1, 2, 3, 9 listopada 1701 (Jacques Cassini), 9, 11, 23 i 25 maja 1702 (G.D. Cassini, J. Cassini oraz Ph. de La Hire'a), 25, 26, 27, 29 grudnia 1702 (G. Cassini, J. Cassini i P. de La Hire), 29 i 30 maja 1703 (G. Cassini, J. Cassini i Ph. de La Hire), 1, 2, 22, 23, 26, 27 czerwca 1703 (G. Cassini, J. Cassini i Ph. de La Hire), 10 i 16 lipca 1703 (G. Cassini, J. Cassini i Ph. de La Hire), 7 stycznia 1705 (Cassini wymieniony jest jako obserwator plam w styczniu, bez dokładnej daty dziennej) i 24 marca 1707 (Cassini); na podstawie: G. S pö re r: Ueber die...(1889) s. 320322 oraz przypisu bibliograficznego $\mathrm{nr}$ 151, R. Wolf: Histoire de l'Académie royale des Sciences. Année 1699-1790, „Mittheilungen über die Sonnenflecken” z. 111860 czerwiec s. 32-33. Lista 
kątowej Słońca ${ }^{176}$, wyznaczanej przez różnych astronomów (np. 1656 r. - G. Cassini, 1671 r. - G. Montanari (1633-1687), 1674 r. - J.C. Calcina ${ }^{177}$, ale także G.B. Riccioli (1598-1671), F. Mezzavacca (zm. 1704) i G.F. Maraldi) ${ }^{178}$, co wcale nie musiało oznaczać obserwacji z zamiarem dostrzeżenia plam. Wiadomo, że i Manfredi obserwował plamy, ale opisy zamieścił w innej swojej książce - Descrizione d’alcune macchie scoperte nel sole l'Anno 1703, wydanej w Bolonii i raczej niedostępnej dla polskiego czytelnika. Jak wynika z wersji opracowania tych obserwacji przez Hoyta i Schattena ${ }^{179}$, wielokrotnie zauważył je wtedy, kiedy nie był ich w stanie dostrzec de La Hire, obserwujący Słońce w te same dni, co Włoch ${ }^{180}$.

Także Flamsteed nie dostrzegł podczas swoich obserwacji plam, mimo że były widoczne na dysku słonecznym, co można wytłumaczyć tym, że już w 1695 r. wykonywał pomiary i katalogował momenty kontaktów Słońca w polu widzenia lunety, posługując się wersją metody tranzytów. Plam nie zaobserwował w następujących dniach (kalendarza juliańskiego): 29 października 1700 r. (plamę lub plamy dostrzegł wówczas Johann Philipp von Wurzelbaur (1651-1725) oraz de La Hire ${ }^{181}$, a wg Spörera także G. Cassini ${ }^{182}$ ), 26 ${ }^{183}$, 28-30 kwietnia oraz 1, 11 i 14 maja 1702 r. (w dniach 6-11 oraz 21-25 maja nowej daty plamy obserwowali G. Cassini, Jacques Cassini (1677-1756) oraz de La Hire'a ${ }^{184}$ ), 19 grudnia 1702 r. (G. Cassini, J. Cassini i Ph. de La Hire ${ }^{185}$ ), 14-15 maja 1703 r. (w dniach 24-31 maja wg nowego kalendarza obserwowali Gian i Jacques Cassini wraz z Philippe de La Hire ${ }^{186}$ ) oraz 15 czerwca 1703 r. (w dniach 18-27 czerwca nowej daty obserwatorami plam byli G. Cassini, J. Cassini i Ph. de La Hire ${ }^{187}$ ).

Manfrediego nie zawiera także informacji o innych plamach, widocznych 21 października 1672 (wówczas powierzchnię Słońca obserwował Bion), oraz 24 i 27 maja 1695, a ponadto 6, 8 i 28 lipca 1684 r. (tabela 1; de La Hire), jak również 27 listopada 1660 r. (J. He weliu sz: Machina..., ks. III, s. 11).

${ }^{176}$ E. Manfre di: dz. cyt. s. 99-238.

${ }^{177}$ Lata życia nie ustalone.

${ }^{178}$ Obserwatorzy skatalogowani jako obserwujący powierzchnię Słońca w wymienionych latach; D.V. Hoyt, K.H. Sc hatte n: Group sunspot... s. 206.

179 ftp.ngdc.noaa.gov/STP/SOLAR_DATA/SUNSPOT_NUMBERS/GROUP_SUNSPOT_NUMBERS/alldata. Strona obecnie niedostępna.

${ }^{180}$ Tamże; 10-11, 18 maja, 22, 24-25 oraz 27-29 czerwca, 2 sierpnia, 3, 18 października, 4, 14, 17 listopada 1705.

${ }^{181}$ Przypis bibliograficzny nr 151, R. Wolf: Histoire...Année 1699-1790 s. 31-32.

${ }^{182}$ G. Spörer: Ueber die...(1889) s. 321.

${ }^{183}$ Nie jest pewne czy Flamsteed wtedy obserwował, bo zamieszczając w katalogu dzień i rodzaj obserwacji rubrykę z wynikami pomiarów pozostawił pustą; J. Fla m steed: Historia coelestis..., ks. II, s. 441.

${ }^{184}$ Przypis bibliograficzny nr 151, R. Wolf: Histoire...Année 1699-1790 s. 32.

185 Tamże, s. 32.

${ }^{186}$ Tamże, s. 32.

187 Tamże, s. 32. 
Również czasy widoczności innych, zauważonych już przez Picarda na przełomie lipca i sierpnia 1676 r. a ponadto obserwowanych w tym samym roku przez Halleya, dwa dni przed dostrzeżeniem pierwszej plamy przez Flamsteeda ${ }^{188}$, pokrywają się z datami pomiarów wysokości Słońca wykonywanych w Gdańsku przez Heweliusza, kiedy ten żadnych plam nie zaobserwował ${ }^{189}$. Dokładniejsza analiza zapisów jego katalogu w Machinae coelestis pars posterior pozwala odróżnić pomiary astrometryczne, które nie są równoznaczne z obserwacjami powierzchni dziennej gwiazdy, od obserwacji plam ${ }^{190}$. I dzięki temu zestawieniu wiadomo kiedy plamy Heweliusz zauważył, a kiedy stwierdził, że plam na Słońcu nie było.

Mierzenie przez Picarda wertykalnej czy horyzontalnej średnicy Słońca nie mogło mu umożliwić dostrzeżenia drobnych szczegółów tarczy słonecznej z powodu małej średnicy obrazu tarczy. Tym bardziej nie byłoby to możliwe wtedy, gdy Heweliusz wyznaczał bez lunety wysokość Słońca ponad horyzontem samym kwadrantem. Możnaby zatem przypuszczać, że plam tych nie dostrzegł, bo katalogował zjawiska widoczne jedynie bez teleskopu. Wniosek taki wydaje się jednak nieprawdopodobny, gdyż katalog wykonanych w ten sposób obserwacji dalekowschodnich nie wymienia aż czterech, a tym bardziej siedmiu plam, widocznych na dysku słonecznym w tym samym czasie ${ }^{191}$. A Heweliusz, w swym katalogu, nie opisał sposobu $\mathrm{w}$ jaki plamy te zostały przez niego dostrzeżone.

Niektóre z innych plam pominięto $\mathrm{w}$ opisie obserwacji, które na pewno nie polegały na wykonywaniu pomiarów astrometrycznych. Przykładem jest plama dostrzeżona przez de La Hire'a 5 maja 1684 r., której kształt i lokalizacja na dysku słonecznym, wywnioskowane z zapisów pozycyjnych, nie umożliwiają identyfikacji jako wschodzącej plamy obserwowanej już wtedy przez Flamsteeda ${ }^{192}$ oraz przypuszczalnie przez Cassiniego ${ }^{193}$. Ponieważ zamieszczanie toru jedynie wybranej plamy, bez rysowania pozostałych grup plam widocznych w tym samym czasie, praktykował kilkadziesiąt lat wcześniej zarówno Scheiner, jak i Heweliusz, można przypuszczać, że podobną ilustrację wykonał w 1684 r. Flamsteed, skupiając się na wyznaczaniu pozycji jednej w kolejnych dniach. Być może jednak tej drugiej nie za-

${ }^{188}$ J. Flamstee d, E. Halley: An Extract... s. 687.

${ }^{189}$ Już Hoyt i Schatten wzmiankowali plamy, których Heweliusz rzekomo nie zauważył w dniach: 26-28, 30 czerwca i 1 lipca; D.V. H oyt, K.H. Schatte n: Overlooked sunspot observations by Hevelius in the early Maunder Minimum,1653 - 1684, „Solar Physics” t. 160: 1995 s. 374.

${ }^{190} \mathrm{~J}$. He weli us z: Machina coelestis..., ks. III, s. 1-30.

${ }^{191}$ A.D. Wittmann, Z.T. Xu: dz. cyt. s. 87-93.

19224 kwietnia 1684 r. Flamsteed żadnych plam nie zaobserwował, raportując pojawienie się plamy przy brzegu tarczy słonecznej dopiero kolejnego dnia (wg kalendarza juliańskiego z początkiem dnia w południe); J. Fla m ste ed: An account... s. 535.

${ }^{193}$ [Tekst bez nazwiska autora]: Description d'une tache qui a paru dans le Soleil ce mois de May dernier 1684, „Journal des sçavans” t. 12: $1684 \mathrm{nr} 15$ s. 197-201; wyd. amsterdamskie z 1709 r., w wydaniu paryskim s. 177-180. 
uważył, podobnie zresztą, jak de La Hire nie dostrzegł plamy 27 czerwca 1684 r., a dopiero dzień później ${ }^{194}$, gdy była odległa od brzegu tarczy o 38”.

Przykładem plamy pominiętej w katalogu, czy też raczej ukrytej w istniejącym opisie, jest zjawisko dostrzeżone w grudniu 1659 r. i pokazywane przez Heweliusza Pierre'owi Des Noyers (1606 lub 1608-1693). Wiadomo o tym z listu napisanego przez Francuza ${ }^{195}$, natomiast w katalogu pomiarów astrometrycznych w Machinae coelestis pars posterior brak stosownej wzmianki ${ }^{196}$. Jednak dokładniejsza analiza łacińskich opisów zamieszczonych w roku kolejnym pozwala odnaleźć opis plamy, która powinna być obserwowana w kolejnych sześciu rotacjach ${ }^{197}$, a wówczas okres widoczności zacząłby się właśnie w grudniu roku 1659. Tę samą grupę opisali w książce Soon i Yaskell ${ }^{198}$ ale niewłaściwie umiejscowili w czasie, gdyż była obserwowana rok wcześniej, niż wynikałoby to z ich relacji. Według autorów miała trwać przez siedem rotacji.

Do 1684 r. plamy wzmiankowane są w opisach dalekowschodnich, w tym dostrzeżone w w latach 1665-1666 ${ }^{199}$, gdy po obserwacji zjawiska w maju $1660 \mathrm{r}$. przez Boyle'a w Europie przez 11 lat czekano potem na zaobserwowanie kolejnej ${ }^{200}$. Szczyty liczby plam pojawiły się wówczas przypuszczalnie w latach 1660 i 1671, o czym bardziej szczegółowo w rozdziale „Związek plam z zorzami”.

Przykłady przedstawione w niniejszym rozdziale wskazują na niewłaściwą interpretację części opisów wykonanych przez obserwatorów Słońca w czasie Minimum Maundera. Relacje te miałyby potwierdzać długotrwałe minimum, a tymczasem plamy na dysku dziennej gwiazdy zostały w tych samych dniach dostrzeżone przez innych albo wzmiankowane obserwacje były w rzeczywistości pomiarami średnicy tarczy słonecznej. Opisy te stawiają także w innym świetle kwestię obserwacji wykonywanych przez Flamsteeda, stosującego w późniejszych latach wersję metody tranzytów, która z pewnością uniemożliwiała mu zauważenie mniejszych, a być może nawet większości plam. Spostrzeżenia te zachęciły do poszukiwania innych relacji, które mogłyby potwierdzić przypuszczenie, że plamy widywane były częściej niż wynikałoby to z różnych opracowań tematu, np. Hoyta i Schattena ${ }^{201}$.

\footnotetext{
${ }^{194}$ P.C. Le Monnier: dz. cyt. s. 323.

195 Z.L. Psz czółkow ska: Korespondenci Jana Heweliusza [w:] Jan Heweliusz, red. M. Pelczar i J. Włodarczyk, Radom 2011, s. 188-189.

${ }^{196}$ J. Heweliusz: Machina coelestis..., ks. III, s. 9.

${ }^{197}$ Heweliusz użył skrótowego zapisu słowa oznaczającego rotację.

${ }^{198}$ W. S o o n, S.H. Ya s kell: The Maunder Minimum and the Variable Sun-Earth connection, Singapur 2003, s. 43.

${ }^{199}$ A.D. Wittman n, Z.T. Xu: dz. cyt. s. 93.

${ }^{200}$ Heweliusz plamy obserwował także później: w czerwcu, lipcu i sierpniu 1660 r. oraz w lutym 1661 r.; J. He weliu s z: Machina coelestis..., ks. III, s. 10-11.

${ }^{201}$ D.V. H oy t, K.H. Sc hatten: Group sunspot... s. 206-208.
} 


\section{Odnalezione opisy archiwalne}

W 1999 r. opublikowano opisy obserwacji plam słonecznych wykonanych w Polsce w 1640 r. przez Wojciecha Strażyca (1610-1650) ${ }^{202}$, powstałe dwa lata wcześniej niż pierwsze rysunki Heweliusza, które odnalazł profesor Jerzy Dobrzycki (19272004). Kilka lat później, w 2006 r., Ricardo Casas opisał wyniki badań ilustracji sporządzonych przez Biona w październiku i listopadzie $1672 \mathrm{r}^{203}$, w czasie trwania głębokiej fazy Minimum Maundera, nieznanych wcześniej badaczom współczesnym.

Odnalazł się także, wzmiankowany już w poprzednim rozdziale, opis plam pokazanych Pierre'owi Des Noyers przez Heweliusza, podczas jego wizyty w gdańskim obserwatorium w 1659 r. Noyers napisał o tym w liście do Ismaëla Boulliau (1605-1694) ${ }^{204}$. W katalogu Heweliusza obserwacje te nie zostały jednak odnotowane, a w zapisach całego roku nie ma nawet jednej notatki o widoczności jakiejkolwiek plamy ${ }^{205}$. Zaobserwowane zostały przypuszczalnie w grudniu, bo wtedy został napisany list i do niedawna nie były wzmiankowane przez żadne współczesne opracowanie okresu Minimum Maundera ${ }^{206}$. Dwa lata później Boulliau ponownie obserwował Słońce będąc gościem w Gdańsku i mimo że wówczas żadnych plam na tarczy nie obserwowano, wzmianki o wspólnych obserwacjach powierzchni dziennej gwiazdy tym razem zostały zamieszczone w rubryce katalogu ${ }^{207}$.

Inną ogólnie dostępną relacją, która została pominięta zarówno przez Spörera, jak i Maundera, o bardzo licznych plamach dostrzeżonych w pierwszych latach XVIII w., jest opracowanie spostrzeżeń Stannyana poczynionych podczas obserwacji wykonanych w okresie od 15 maja do 17 lipca 1704 r. $^{208}$, czyli w schyłkowej fazie Minimum. Obserwacje te zostały natomiast wymienione w opracowaniu Hoyta i Schattena ${ }^{209}$.

Nieznane opisy plam słonecznych z XVII w. dostrzeżonych przed 1645 r. odnalazł także w ostatnich latach Jose Vaquero. Wyznaczył ponadto nowe wartości liczby Wolfa dla przełomu lat trzydziestych i czterdziestych, zmieniając przy tym koncepcję samego Minimum. Według niego okres mniej licznych plam miałby się zacząć stopniowo już dwa cykle wcześniej niż wynikałoby to z cezury przyjętej przez Maun-

${ }^{202}$ J. D o b rzycki: Saturn, aristotelian astronomy, and Cracow astronomers: an episode from the early years of telescopic astronomy, „Journal for the History of Astronomy” t. 30: 1999 s. 121-129.

${ }^{203}$ Oryginalne rysunki odnaleźć można w: N. Bi on : dz. cyt. s. 376.

${ }^{204}$ Już w 1645 r., czyli 42 lata przed ukazaniem się Principiów Newtona, przypuszczał istnienie zależności siły grawitacyjnej od odwrotności kwadratu odległości. J. No r th : Historia astronomii... s. 242.

${ }^{205} \mathrm{~J}$. Heweli us z : Machina coelestis..., ks. III, s. 8.

${ }^{206}$ Z.L. Ps z czółkow ska: dz. cyt. s. 188-189.

${ }^{207}$ J. Heweliusz: Machina coelestis..., ks. III, s. 11-12. Obserwacje te zostały wykonane 16 i 20 marca oraz 30 sierpnia $1661 \mathrm{r}$.

${ }^{208}$ Stannyan: dz. cyt. s. 1756-1762.

${ }^{209}$ D.V. H oyt, K.H. S chatten : Group sunspot... s. 207. 
dera $^{210}$. Do okresu Minimum wliczone zostałyby wówczas także obserwacje wykonane w latach 1642-1644, gdy obserwował Heweliusz, jak również przez Wojciecha Strażyca w $1640 \mathrm{r}^{211}$.

Poza jedną plamą, dostrzeżoną w 1695 r., której obserwatorem był Giacomo Filippo Maraldi, innych w ostatniej dekadzie XVII w. nie obserwowano. Pierwszą, którą Spörer wymienił, jako widoczną po dłuższej przerwie, dostrzeżono dopiero 7 listopada $1700 \mathrm{r}^{212}$.

„Memoires” z 1702 r. wzmiankują Maraldiego, jako obserwatora w 1695 r., gdy ten plamę na Słońcu obserwował w dniach 24 i 26 maja, choć artykuł dotyczy innej, zauważonej 22 maja 1702 r. przy wschodnim brzegu tarczy słonecznej. Maraldi, jak zaznaczył Cassini w swoim tekście, zaobserwował wcześniejsze zjawisko w tym samym obszarze dysku ${ }^{213}$. Spörer, tworząc potem swoje zestawienie plam widocznych w latach 1672-1713, wykorzystał jednak inny opis, zamieszczony w drugim tomie „Histoire” z roku $1733^{214}$, w którym nieznany autor napisał co innego. Według niego plama pojawiła się dopiero 27 maja, ale przy zachodnim brzegu dysku słonecznego, podczas gdy wcześniej miała być niewidoczna. Dalsza część opisu wzmiankuje przemieszczenie się struktury na niewidoczną z Ziemi półkulę Słońca między 30 a 31 maja. Gdy ostatniego dnia miesiąca o godzinie 10 zostały powtórzone obserwacje okazało się, że po plamie nie pozostał już żaden ślad. Obserwatorami zjawiska mieliby być de La Hire i Maraldi. Sam de La Hire, mimo że miał zwyczaj opisywać w czasopiśmie zaobserwowane plamy, o zjawisku widocznym w 1695 r. nie napisał nic. Spörer i Maunder skatalogowali wyłącznie tę drugą relację ${ }^{215}$, podczas gdy ze szczegółów obu opisów wynika, iż obserwowano wówczas dwie plamy. Jedną plamę widoczną w 1695 r. wymienia również histogram publikacji Ribesów ${ }^{216}$, choć sam wykres nie jest dokładny, bo nie można się doliczyć kilku innych plam z roku $1684^{217}$, jak i rzekomo zaobserwowanych wcześniej przez Picarda w 1677 r. ${ }^{218}$.

${ }^{210}$ J.M. Va qu e r o: Historical records of solar grand minima: a review [w:] Comparative Magnetic Minima: Characterizing quiet times in the Sun and stars, Proceedings IAU Symposium Nr 286, red. C.H. Mandrini i D.F. Webb, Cambridge 2011, s. 387 i 390.

${ }^{211}$ J. Dobrzycki: dz. cyt. s. 121-129.

${ }^{212}$ G. Spörer: Ueber die...(1889) s. 321.

${ }^{213}$ G.D. Cassini: D'une nouvelle Tache dans le Soleil. Par M. Cassini le fils, „Memoires de mathématique et de physique tirés des registres de l'Académie Royale des Sciences", t. 4: 1702 s. 140; wyd. paryskie, bez bieżącej numeracji tomów.

214 [Komunikat bez nazwiska autora]: Diverses observations astronomiques, „Histoire de l'Académie Royale des Sciences", t. 2: 1733 s. 264.

${ }^{215}$ Katalog Le Monniera nie umożliwia weryfikacji tej obserwacji, gdyż zapisy zestawienia kończą się na 30 grudnia 1685 r.; P.C. Le Monni er: dz. cyt. s. 366.

${ }^{216}$ J.C. Ribes, E. Nesme-Ribes: The solar... s. 556.

${ }^{217}$ P.C. Le Monnier: dz. cyt. s. 314-328.

218 Tamże, s. 233-234. 
Dwie plamy na Słońcu wzmiankowane są także w jednym z listów, który został napisany na początku 1698 r. przez Johanna Abrahama Ihle, ale zawiera jedynie kilka dat obserwacji z przełomu lat 1697 i 1698, gdy tarcza słoneczna pozostawała bez plam ${ }^{219} \mathrm{i}$ brak informacji o tym, kiedy te dwie zostały zauważone. Opis ten może mieć związek z olbrzymim szczytem zorzowym w latach 1698-1699, ale też odnosić się do widocznych właśnie w maju 1695 lub wcześniej.

Natomiast tylko o jednej plamie, zaobserwowanej zresztą w okresie wielu lat, napisał Ihle w późniejszym liście datowanym na wrzesień $1700 \mathrm{r}^{220}$. Znów jednak nie podał daty widoczności, ale wiadomo, że wcześniej dwukrotnie dostrzegł plamy w $1687 \mathrm{r}$. - 1 października i 1 listopada ${ }^{221}$. Możliwe, iż pisząc list stwierdził, że obserwował jedną i tę samą plamę, zatem zdawkowo wspomniał tym razem tylko o jednej, ale możliwe także, że napisał o plamie widocznej później niż opisane we wcześniejszym jego liście. Hoyt i Schatten ${ }^{222}$ wzmiankują ponadto inną plamę dostrzeżoną przez Ihle w roku $1680^{223}$. Liczba plam zaobserwowanych w czasie ostatniej dekady zwiększa się tym samym do dwu, ale być może dostrzeżonych zostało wtedy pięć.

Flamsteed, co wynika z zapisów Historia coelestis Britannica, obserwował powierzchnię Słońca 30 czerwca roku $1703^{224}$ i dostrzegł trzy plamy. Hoyt i Schatten skatalogowali natomiast trzy dni w tym samym roku ${ }^{225}$, a Spörer plam tych nie zewidencjonował w ogóle.

Spörer w swoim zestawieniu zamieścił także informację o plamie dostrzeżonej 12 maja 1688 r., powołując się na źródłowy opis, zaczerpnięty z tomu X „Memoires” z roku $1730^{226}$. Inny rocznik czasopisma, z 1778 r., wzmiankuje 5 maja 1688 r. $^{227}$, zaś z roku $1702^{228} 6$ i 13 maja 1688 r., w kontekście plamy zaobserwowanej w tym samym miesiącu, ale w roku 1702. Spörer skatalogował jedynie plamę widoczną 12 maja 1688 r., pomijając inne daty widoczności. Katalog Hoyta i Schattena daty te wymienia, choć nie wzmiankuje widoczności plam²29.

${ }^{219}$ G. Kirch: dz. cyt., t. II, s. 259; list z numerem 594.

${ }^{220}$ Tamże, s. 409-410, list z numerem 745, datowany na 26 września 1700 r.

${ }^{221}$ H.E. Land s berg: dz. cyt. s. 184.

222 ftp.ngdc.noaa.gov/STP/SOLAR_DATA/SUNSPOT_NUMBERS/GROUP_SUNSPOT_NUMBERS/alldata. Strona obecnie niedostępna.

${ }^{223}$ Ihle, jako obserwator w roku 1680, został także wymieniony w publikacji: D.V. Hoyt, K.H. S ch atten: How well was the Sun observed during the Maunder Minimum?, „Solar Physics” t. 165: 1996 s. 190.

${ }^{224}$ J. Fla ms tee d: Historia coelestis..., ks. II, s. 462.

225 D.V. Hoyt, K.H. Schatten: Observations of sunspots by Flamsteed during the Maunder Minimum, „Solar Physics” t. 160: 1995 s. 380.

${ }^{226}$ Według Spörera opis na stronie 727. G. S pörer: Ueber die...(1889) s. 320.

${ }^{227}$ J. La Lande: dz. cyt. s. 402.

${ }^{228}$ G.D. Cassini: De la Tache... wyd. paryskie s. 133-134.

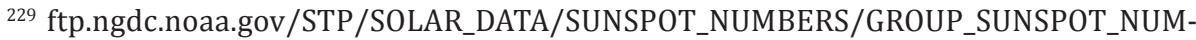
BERS/alldata. Strona obecnie niedostępna. 
Cassini pozostawił także rysunki plam wykonane 30 października oraz w dniach: 1, 2, 3, 18, 19, 21, 22, 23, 24, 25, 26, 27, 28, 29 i 30 listopada 1676 r. ${ }^{230}$. Część tych ilustracji, poza wykonanymi 2 i 3 listopada, ma odpowiedniki w osiemnastowiecznym katalogu Le Monniera na planszy prezentującej spostrzeżenia Picarda ${ }^{231}$ lub została skatalogowana w części opisowej. Daty wykonania obserwacji w dniach 2, 3, 18 i 19 listopada uszły natomiast uwadze zarówno Spörera ${ }^{232}$, jak i Maundera ${ }^{233}$, ale znane były Wolfowi ${ }^{234}$. Wymienione zostały również w katalogu Hoyta i Schattena ${ }^{235}$.

Przykłady zestawione w niniejszym rozdziale potwierdzają, że opublikowana w 1889 r. przez Spörera lista plam ${ }^{236}$ dostrzeżonych w latach 1672-1713 jest nieco niekompletna. Wiadomo także, że badacz niemiecki pominął plamy opisane przez Derhama. Inaczej prezentuje się również okres ostatniej dekady XVII w., także poprzez wzmianki o plamach odnalezione w korespondencji Kircha, przedstawiany we współczesnych opracowaniach tak samo, jak za czasów Spörera.

\section{Tempo rotacji słońca wyznaczone z obserwacji plam}

Choć dokładność rysunków tarczy słonecznej z plamami wykonanymi przez Scheinera w 1611 r. była mała, co łączyło się z pomijaniem szeregu istotnych szczegółów na ilustracjach o niedużej średnicy ${ }^{237}$, tempo rotacji Słońca w tym okresie można szacować na podstawie innych rycin wykonanych przez Harriota w latach 1611-1613 ${ }^{238}$ i Galileusza w $1612 \mathrm{r}^{239}$. Wyznaczenie prędkości wirowania Słońca umożliwiły także obrazy dysku słonecznego zamieszczone przez Scheinera w Rosa Ursina, których staranność wykonania jest już porównywalna z późniejszym warsztatem Heweliusza. 26 dużych plansz (przykład na rys. 2) pozostawionych przez gdańszczanina, na których przedstawił tory plam widocznych w latach 1642-1644, posłużyło natomiast do wyznaczenia tempa rotacji słonecznej w okresie bezpośrednio poprzedzającym Minimum Maundera ${ }^{240}$. Heweliusz nie posługiwał się jednak

${ }^{230}$ G.D. Ca s sin i: Suite des observations... s. 11-13, wyd. amsterdamskie; w wyd. paryskim s. 8-9.

${ }^{231}$ P.C. Le Monnier: dz. cyt. plansza II, s. nienumerowana.

${ }^{232}$ G. Spörer: Ueber die...(1889) s. 320.

${ }^{233}$ E.W. Maunder: dz. cyt. s. $140-145$.

${ }^{234}$ R. Wolf: Histoire et Mémoires... en 1666 jusqu'à 1699... s. 30-31.

235 ftp.ngdc.noaa.gov/STP/SOLAR_DATA/SUNSPOT_NUMBERS/GROUP_SUNSPOT_NUMBERS/alldata. Strona obecnie niedostępna.

${ }^{236}$ G. Spöre r: Ueber die...(1889) s. 319-324.

${ }^{237}$ Ch. Scheiner : De maculis... wklejka.

${ }^{238}$ R.B. Herr: dz. cyt. s. 1079-1081.

${ }^{239}$ Galile us z: Istoriae... s. 40-60.

${ }^{240} \mathrm{C}$. A bar b a nell, H. Wö hl: Solar rotation velocity as determined from sunspot drawings of J. Hevelius in the 17th century, „Solar Physics” t. 70: 1981 s. 197-203. 
podczas tych obserwacji mikrometrem, nie pozostawił żadnych wyników takich pomiarów ${ }^{241}$ i być może również on pozycje na tarczy przedstawił nieco niewłaściwie $^{242}$. Jego rysunki stanowią także podstawę do określenia wartości liczb Wolfa w okresie bezpośrednio poprzedzającym Minimum ${ }^{243}$.

W 1993 r. wartości tempa rotacji na równiku słonecznym w dwu fazach Minimum Maundera (przed i po 1700 r.) zaprezentowali Ribesowie ${ }^{244}$. Tempo to zostało wyznaczone na podstawie obserwacji wykonywanych od 1666 r. przez Picarda, a potem przez de La Hire’a. Obydwaj pozostawili mało rysunków, ale wykonywali pomiary pozycyjne plam, które umożliwiły wyznaczenie zmian współrzędnych heliograficznych. Oszacowana przez Ribesów, a odczytana z ilustracji w ich artykule, wartość tempa rotacji słonecznej na równiku w latach 1666-1700 (a dokładniej 1672-1695) sięgnęła 14, ${ }^{\circ} 2$ na dobę ${ }^{245}$, zaś w schyłkowej fazie Minimum przekroczyła 14,4 na dobę. Wartości te nie różnią się jednak istotnie od wyników wyznaczonych z obserwacji wykonanych w latach 1954-1986 przez M.A. Kambry'ego i J. Nishikawę ${ }^{246}$, które mieszczą się w zakresie $14,{ }^{\circ} 19-14,{ }^{\circ} 65$ na dobę. Tempo to było najmniejsze podczas minimum w 1963 r., zaś największe w szczycie niskiego cyklu, w latach 1969 i 1972. Natomiast Ribesowie porównali wyniki swoich oszacowań z pomiarami sprzed 1954 r., opracowanymi przez Freda Warda, wykazując, że tempo rotacji Słońca na równiku przed końcem XVII w. było takie, jak współczesne, ale na szerokości heliograficznej ponad $20^{\circ}$.

Uwzględnienie różnicy odległości między Ziemią a plamą oraz Ziemią i środkiem Słońca nie umożliwiło mi uzyskania innych wartości współrzędnej niż wzmiankowane w zestawieniach Spörera ${ }^{247}$ i Maundera ${ }^{248}$. Ale z oryginalnych zapisów zamieszczonych w katalogu Le Monniera wynika jednak, że kilka z tych plam francuscy astronomowie zaobserwowali na szerokościach nieznacznie przekraczających $20^{\circ}$, mimo że wg rysunku w publikacji Ribesów rzadko która pojawiła się na szerokości większej niż $15^{\circ}$.

Najdłuższy okres rotacji Słońca w czasie Minimum Maundera wyznaczył natomiast Casas na podstawie rysunku wykonanego przez Biona w roku 1672 (patrz rysunek 5), który powinien być wtedy równy 36 dniom. Wynika z tego, że pozycji

${ }^{241}$ J. He we li u s z: Selenographia sive... s. 500-525; tenże, Machina coelestis..., ks. III, s. 1-30.

${ }^{242}$ J.A. Eddy, P.A. Gilman, D.E. Trotter: dz. cyt. s. 10.

${ }^{243}$ Nie wszystkie jednak z zaobserwowanych przez Heweliusza plam znalazły się na rysunkach w katalogu. Nie ma tam np. dużej plamy, widocznej bez lunety. Plamę obserwował 1, 11 i 13 stycznia 1644 r., a wzmianka o zjawisku została zamieszczona w opisie tekstowym. J. Heweliu sz: Selenographia sive ... s. 513.

${ }^{244}$ J.C. Ribes, E. Nesme-Ribes: The solar... s. 558-559.

245 Tamże, s. 559.

${ }^{246}$ M.A. Ka m bry, J. Ni i h i kawa: Solar differential rotation derived from sunspot observations, „Solar Physics” t. 126: 1990 s. 89-100.

${ }^{247}$ G. Spörer: Ueber die...(1889) s. 319-324.

${ }^{248}$ E.W. Maunder: dz. cyt. s. 142-143. 
plam na tarczy co najmniej w listopadzie nie wyznaczał mikrometrem. Mniejsze niż współczesne tempo rotacji wyznaczone zostało także na podstawie rysunków Flamsteeda, ilustrujących zmiany pozycji plamy widocznej w $1684 \mathrm{r}^{249}$.

Ograniczenie szerokości heliograficznej plam pojawiających się w czasie Minimum do $20^{\circ}$, jakie wynika z artykułu Ribesów ${ }^{250}$, powinno być może dotyczyć jedynie największych grup, takich jakie Picard i de La Hire mogli dostrzec podczas obserwacji astrometrycznych. Ale wiadomo także, że w roku 1705 Manfredi ${ }^{251}$ zaobserwował dwie plamy na szerokości heliograficznej aż $30^{\circ}-40^{\circ}$, których najwyraźniej brak w opracowaniu spostrzeżeń de La Hire'a oraz na liście Spörera ${ }^{252}$.

Co ciekawsze, w 1776 r. Joseph J.L. de La Lande (1732-1807) opublikował listę szerokości heliograficznych plam, które sam ustalił korzystając z obserwacji wykonanych przez Scheinera w latach 1623-1627 i opisanych w Rosa Ursina oraz przez Heweliusza w latach 1642-1644, opublikowanych w Selenographia ${ }^{253}$. Okazało się, że plamy na rycinach powstałych w Gdańsku nie oddaliły się od słonecznego równika bardziej niż o $18^{\circ}$, choć być może powstały w minimum cyklu jedenastoletniego. Natomiast na ilustracjach Scheinera zaledwie kilka plam pojawiło się na szerokości heliograficznej nieco większej niż $20^{\circ}$, ale żadna nie sięgnęła $25^{\circ}$.

Z krótkiej dyskusji przedstawionej tutaj wynika, że wyniki szacowania tempa rotacji słonecznej w czasie Minimum Maundera wydają się potwierdzać przypuszczenie, że tempo to mogło być w rzeczywistości zbliżone do współczesnego, skłaniając tym samym do wniosku, że podobna mogła być również aktywność plamowa. Mniejsze wartości parametru wyznaczone z obserwacji wykonanych w pierwszej połowie wieku $\left(13,{ }^{\circ} 3^{254}\right.$ lub $13,{ }^{\circ} 59^{255}$ - Harriot, $13,{ }^{\circ} 25$ i 13, 38 - Scheiner $\left.{ }^{256}\right)$, wskazujące na mniejszą prędkość wirowania Słońca, mogą być bezpośrednim skutkiem analizowania rysunków o mniejszej dokładności, spowodowanej np. brakiem przyrządu, który mógłby pełnić funkcję mikrometru.

${ }^{249}$ J.M. Vaqu er o, F. Sá n ch e z-Baj o, M.C. Galleg o: A measure of the Solar Rotation During the Maunder Minimum, „Solar Physics” t. 207: 2002 s. 219-222.

${ }^{250}$ J.C. Ribes, E. Nesme-Ribes: The solar... s. 555 i 558.

${ }^{251} \mathrm{E}$. Baiada, R. Merighi: The revival of solar activity after Maunder Minimum in reports and observations of E. Manfredi, „Solar Physics” t. 77: 1982 s. 357-362.

${ }^{252}$ G. Spörer: Ueber die...(1889) s. 322.

${ }^{253}$ J. La Land e: Mémoire sur les Taches du Soleil, et sur sa rotation, „Memoires de mathématique et de physique tirés des registres de l'Académie Royale des Sciences” t. 78: 1776 s. 487-492; wyd. paryskie bez bieżącej numeracji tomów.

${ }^{254}$ R.B. Herr: dz. cyt. s. 1079.

${ }^{255}$ R. Casas, J. M. Vaquero, M. Vázquez: dz. cyt. s. 380.

256 Tamże, s. 380. 


\section{Związek plam z zorzami}

W 1894 r. Agnes Clerke ${ }^{257}$ potwierdziła ideę Spörera, analizując historyczne zapisy obserwacji zórz wykonanych w okresie Minimum Maundera. Wiadomo, że swoje spostrzeżenie oparła na zestawieniach zamieszczonych w Traite Jeana de Mairana (1678-1771), którego drugie wydanie zawiera już znacznie więcej dat widoczności świeceń zorzowych w tym czasie ${ }^{258}$. Clerke korzystając z pierwszego, pominęła ponad 120 dni z zorzami w latach $1645-1717^{259}$, ale poparła koncepcję zmienionego poziomu aktywności słonecznej w drugiej połowie XVII w. W roku 1976 John Eddy, publikując w „Science” swój artykuł, wymienił natomiast liczbę 77 dni, powołując się w przypisie 37 na zestawienie wykonane przez Hermanna Fritza $(1830-1893)^{260}$.

Gdy w 1985 r. ukazał się obszerny katalog zorzowy ${ }^{261}$ zjawisk dostrzeżonych od roku 1000 na obszarze średnich szerokości geograficznych ${ }^{262}$, łączna liczba dni z zorzami podczas Minimum Maundera zwiększyła się do $189^{263}$. Wiele z tych opisów zostało zaczerpniętych z podobnego wcześniejszego zestawienia autorstwa Linka z 1964 r. W swojej publikacji zamieścił oryginalne relacje, które poddał weryfikacji zanim znalazły się na liczącej 79 pozycji końcowej liście.

Link pominął chociażby zjawiska opisane przez Cassiniego, widoczne podczas kolejnych dni na początku lipca 1687 r. Obserwacje te przypadły na okres letni, gdy na szerokości geograficznej Paryża co roku obserwowane jest zjawisko całonocnego zmierzchu. Do katalogu Křivský’ego i Pejmla trafiły natomiast wyłącznie dni stanowiące cezury czasowe relacji Włocha.

Przesłanką, która wydaje się jednak potwierdzać większą aktywność zorzową w 1687 r., są liczne i duże plamy, które zaobserwował wtedy w Lipsku Kirch, a o których ani Link ani Eddy nie mogli nic wiedzieć, bo opisy te ujrzały światło dzien-

\footnotetext{
${ }^{257}$ A.M. Clerke: dz. cyt. s. 206-207.

${ }^{258} \mathrm{~J}$. de Mairan: Traité physique et historique de l'aurore boréale, Paryż 1754, wyd. II.

${ }^{259}$ Miesiąc przed opublikowaniem listu Clerke ukazał się w tym samym czasopiśmie i pod takim samym tytułem artykuł Maundera, wg którego czas długiego Minimum zakończył się wraz z bardziej wyraźnym szczytem liczby plam w 1718 r.; E.W. M a u n d er: A prolonged sunspot minimum, „Knowledge” t. 17: 1894 s. 174.

${ }^{260}$ J.A. E d dy: The Maunder Minimum, „Science” t. 192: 1976 nr 4245 s. 1193 i 1202; w zestawieniu Křivský'ego i Pejmla z roku 1985 (patrz przypis kolejny) można doliczyć się jedynie 68 dni zorzowych w latach 1645-1717, dla których źródłowym katalogiem powinien być katalog Fritza, ale aż 28 dni w latach 1616-1717. Katalog ten umożliwia zatem odszukanie jedynie połowy dni ze wzmiankowanych w „Science”, gdzie cezurą okresu jest rok 1715.

${ }^{261}$ L. Křivský, K. Pejml: Solar activity, aurorae and climate in Central Europe in the last 1000 years, „Travaux Géophysiques” t. 33: 1985 s. 77-151.

${ }^{262}$ Szerokości mniejsze niż $55^{\circ}$.

${ }^{263}$ Do roku 1717. W latach $1716-1717$ zestawiono w tym katalogu 29 dni zorzowych; L. Křivský, K. Pejml: dz. cyt. s. 41.
} 
ne dopiero w 1980 r. $^{264}$. Plamy te widywane były od końca maja do grudnia, mimo że Cassini nie dostrzegł żadnej, obserwując podobno uważnie Słońce przez cały rok ${ }^{265}$, podobnie jak de La Hire ${ }^{266}$.

Link nie zdecydował się uznać za opisy zórz także innych przekazów historycznych, dotyczących otoków świetlnych, które mogłyby być relacjami o zaobserwowaniu halo. Przykładem jest relacja z 21 kwietnia 1670 r. $^{267}$ wzmiankująca również ruch, nietypowy dla zjawisk powodowanych załamywaniem odbitego od Księżyca światła słonecznego na kryształach chmur lodowych. W opisie tym nie odnotowano ponadto widoczności naturalnego satelity, którego światło jest niezbędne by wytworzyć halo w porze nocnej, a który powinien być wówczas bliski nowiu ${ }^{268}$.

W roku 1991 Ludwig Schlamminger ${ }^{269}$ opublikował histogram grupujący 121 dni, gdy zorze widoczne były w okresie Minimum, a zostały dostrzeżone z terenu Europy Centralnej, czyli z obszaru średnich szerokości geograficznych. Znając lata szczytów liczby plam w drugiej połowie XVII w., wyznaczone jeszcze przez Wolfa, stwierdził, że potwierdzają efekt późniejszych o dwa lata, względem szczytów liczby plam, szczytów liczby dni zorzowych w cyklu, odkryty w połowie XIX w. przez Fritza ${ }^{270}$.

W roku 2004 r. opublikowane zostały nieznane wcześniej opisy zórz, obserwowanych także w latach Minimum Maundera, ale z terenu Dalekiego Wschodu. Przybyło wtedy 14 dni przed rokiem 1700 i dalsze 6 w schyłkowych latach okresu $^{271}$.

${ }^{264}$ Publikacja Landsberga ukazała się 4 lata po artykule Eddy'ego w „Science”. Plam dostrzeżonych przez Kircha w latach: 1679, 1681, 1687 i 1688 oraz przez Ihle'ego w roku 1687 nie ma na liście Spörera. Także przypisy bibliograficzne Wolfa zamieszczane w czasopiśmie, które wydawał, nie zawierają informacji by Kirch opublikował wyniki swoich obserwacji wykonanych w tym właśnie roku. Do 1980 r. pozostawały skatalogowane jedynie w jego dziennikach; H.E. Land sb erg: dz. cyt. s. 181-191.

${ }^{265}$ Uwaga została zamieszczona na liście w publikacji Maundera (E.W. Maunder: dz. cyt. s. 142).

${ }^{266}$ J.C. Ribes, E. Nesme-Ribes: The solar... s. 556.

${ }^{267}$ F. Link: Observations et catalogue des aurores boréales apparues en occident de 1601 à 1700, „Geofysikálni Sbornik” t. 212: 1964 s. 33.

${ }^{268}$ Faza Księżyca według Stellarium.

${ }^{269}$ L. Schla mming er: Aurora borealis lag during the Maunder Minimum, „Solar Physics” t. 131: 1991 s. 411-414.

${ }^{270}$ Fritz skatalogował zaledwie $18 \mathrm{dni}$ z zorzami w latach Minimum przed początkiem XVIII w., które zupełnie nie potwierdzają tej relacji. Zawartość katalogu Fritza ustaliłem na podstawie opracowania: L. Křivský, K. Pejml: dz. cyt. s. 40-41. W publikacji w „Kwartalniku Historii Nauki i Techniki" z 2005 r. niepoprawnie opisałem histogram, który zawiera zorze z publikacji Schlammingera, a nie jedynie skatalogowane przez Fritza; R. Rek: Obserwacje plam... s. 234.

${ }^{271}$ E.H. Lee, Y.S. Ahn, H.J. Yang, K.Y. Chen: The sunspot and auroral activity cycle derived from Korean historical records of the 11th-18th century, „Solar Physics” t. 224: 2004 s. 373-386. 
Podobne opisy są wciąż odnajdywane. Vaquero z Vázqeuzem wzmiankują zorzę widoczną 17 września 1672 r. ${ }^{272}$, której brak w katalogach zorzowych, podobnie jak nie ma tam zorzy opisanej przez Heweliusza, który zjawisko obserwował 22 września 1659 r. ${ }^{273}$. Wśród zestawień brak także zórz opisanych w listach przez Flamsteeda ${ }^{274}$.

Zapomnianym wydaje się być katalog Wolfa, opublikowany w $1857 \mathrm{r}^{275}$. Zestawienie to zwiększa liczbę dni zorzowych w czasie Minimum Maundera ${ }^{276}$ o 125 277 i zawiera bardzo liczne daty widoczności zórz w latach 1698-1699 (40 i 20), dla których nie ma jednak pokrycia w szczycie liczby plam. Katalog ten pozwala wyznaczyć maksima liczby dni z zorzami na lata 1707 i 1719, czyli te same, co katalog Křivský'ego i Pejmla, potwierdzające poprzez spostrzeżenie Fritza szczyty liczby plam w latach 1705 i 1718. Maksima liczby zórz w latach: 1687, 1698-1699, 1707 oraz $1719^{278}$ wyznaczają ponadto interwały czasowe mieszczące się w zakresie zmian długości cyklu plamowego po roku $1749^{279}$.

Publikacji Wolfa brak w bibliografii współczesnych studiów aktywności zorzowej z powodu niedostępności informacji o współrzędnych geograficznych miejsca obserwacji, których powinny dostarczyć katalogi źródłowe. Szczegółu tego dla okresu Minimum, poza relacją Cassiniego z roku 1687, nie precyzuje zestawienie Boué ${ }^{80}$, ale również źródłowy Traite de Mairana ${ }^{281}$, zawierający dodatek prezentujący wykaz dat zebrany wcześniej przez Frobesa z licznymi zorzami w latach 1698-1699282.

${ }^{272}$ J.M. Va que ro, M. Vázque z: The Sun... s. 303.

${ }^{273}$ J. Heweli us z: Machina ..., ks. II, s. 170.

${ }^{274}$ J. Fla mstee d: The correspondence..., t. 2, s. 1011-1014 (zorza widoczna po 25 grudnia 1681 r., list nr 895); s. 1008-1010 (widoczna 24 marca 1703 r., list 894); s.1017 (obserwowana między 8 kwietnia a 4 maja 1703 r., list 898).

${ }^{275}$ R. Wolf: Nordlichtkatalog und Vergleichung des jährlichen Ganges in dieser Erscheinung mit dem der Sonnenflecken, „Mittheilungen über die Sonnenflecken von Dr. Rudolf Wolf” z. 5: 1857 wrzesień s. 83-102.

${ }^{276}$ W latach 1645-1717.

${ }^{277}$ W tym 13 w latach 1716-1717. Wzmiankowanych 125 dni zorzowych brak w katalogu autorów z Czechosłowacji, katalogu Lee i in., (E.H. Lee, Y.S. A h n, H.J. Yang, K.Y. Chen: dz. cyt. s. 382) oraz katalogu Schrödera (W. Schrö e d er: Auroral frequency in the 17th and 18th centuries and the 'Maunder minimum', „Journal of Atmospheric and Terrestrial Physics" t. 41: 1979 s. 445-446).

${ }^{278}$ Kolejny wyraźny szczyt zorzowy byłby już w roku w 1722, co może być skutkiem wzrastającej liczby obserwacji. Szczyty zorzowe według L. Křivský, K. Pejml: dz. cyt. s. 77-151 oraz R. Wolf: Nordlichtkatalog und... s. 83-102.

279 9-13 lat; K. Petrovay: Solar Cycle Prediction, „Living Reviews in Solar Physics” t. 7: 2010 s. 28-29.

${ }^{280}$ B o u é: Chronologischer Katalog der Nordlichter bis zum Jahre 1856, samt einer Bibliographie über diese Erscheinung, „Sitzungsberichte der Kaiserlichen Akademie der Wissenschaften" t. 2: 1856 z. 1 s. 3-74.

${ }^{281}$ J. de Mairan: dz. cyt. s. 467-480.

${ }^{282}$ Tamże; szerokość geograficzna znana jest natomiast dla zórz obserwowanych przez Marię Kirch (1670-1720) od roku 1707 w Berlinie. Daty tych obserwacji de Mairan zamieścił w odrębnym dodatku; s. 499-502. 
Przesłanki za ciągłością periodyczności Schwabego w okresie Minimum Maundera dostarcza także analiza okresu rozciągającego się na lata 1661-1671, gdy zorze równonocne ${ }^{283}$ widoczne były wyłącznie w pierwszej połowie roku, co mogło być skutkiem asymetrii powierzchni polarnych dziur koronalnych, która może utrzymywać się przez okres od jednego przebiegunowania do kolejnego ${ }^{284}$. Na tej podstawie można wyznaczać lata szczytów liczby plam na rok 1660 i 1671.

Również zjawiska widoczne w pozostałych miesiącach, poza bliskimi równonocom, grupują się w małe szczyty, oddzielone interwałami mieszczącymi się w zakresie zmienności długości cyklu jedenastoletniego ${ }^{285}$, choć dni zorzowych przed 1687 r. skatalogowano stosunkowo mało. Ponadto pojawiają się wtórne maksima w połowie cyklu, znane z opracowania Sama Silvermana, który analizował m.in. cykliczność zórz dostrzeżonych z obszaru średnich szerokości geograficznych w latach 1500-1948 286 .

Zestawienia opisów aktywności zorzowej w czasie Minimum Maundera potwierdzają, że zórz zaobserwowano kilkakrotnie więcej niż wzmiankuje artykuł Eddy’ego opublikowany w 1976 r. w „Science”. Dodatkowo przesłanki za ciągłością zorzowego cyklu 11-letniego w tym okresie skłaniają ku ciągłości także i 11-letniego cyklu plamowego, co powinno się łączyć z aktywnością plamową taką, jak obserwowana współcześnie.

\section{Wnioski dla teorii współczesnej}

Długie minimum liczby plam zostało przypomniane w 1976 r. przez Johna Eddy'ego w kontekście badań zmian obfitości izotopu radioaktywnego węgla, gdy zamieścił on artykuł przeglądowy w czasopiśmie „Science”. Zacytował spostrzeżenia Picarda, Flamsteeda i Gian Domenico Cassiniego ${ }^{287}$, a także opisy zórz i korony słonecznej wykonane w tym czasie. Jako pierwszy nazwał ten okres nazwiskiem Maundera.

Amerykanin spopularyzował teorię, która łączy brak plam w okresie Minimum z większą obfitością izotopu węgla zasymilowanego w tamtym czasie przez drzewa. Eddy dysponował danymi umożliwiającym analizę tej zmienności, które jednak nie

${ }^{283}$ Zjawiska widoczne jedynie w kilku miesiącach roku, w lutym, marcu, kwietniu, wrześniu i październiku, które wybrałem z katalogu: L. Křiv s ký, K. Pejml: dz. cyt. s. 77-151 oraz R. Wolf: Nordlichtkatalog und... s. 83-102.

${ }^{284}$ A. Priga n cová, M. B i e le ková: Long term trend in the seasonal variation of the magnetospheric response [w:] Solar-Terrestrial Predictions - IV, Proceedings of a Workshop at Ottawa, Canada, May 18-22, 1992, t. 2, red. J. Hruska i in., Boulder 1993, s. 636-648.

${ }^{285}$ Zjawiska widoczne w kolejnych latach poza marcem, kwietniem, wrześniem i październikiem, czyli okresami aktywności zorzowej związanej ze słonecznymi strukturami polarnymi, wybrane z katalogu L. Křivs ký, K. Pejml: dz. cyt. s. 77-151.

${ }^{286}$ S.M. Silverman: Secular variation of the aurora for the past 500 years, „Reviews of Geophysics" t. 30: $1992 \mathrm{nr} 4$ s. 338.

${ }^{287}$ J.A. Eddy: The Maunder... s. 1190. 
pokrywały drugiej połowy XVII w. w sposób ciągły. Nie mógł zatem zauważyć ani dyskutować ciągłości cyklu jedenastoletniego w powstałym $\mathrm{w}$ tym czasie drewnie. Swoje wnioski opierał jedynie na spostrzeżeniu Stuivera z 1961 r. ${ }^{288}$, który stwierdził antykorelację między liczbą plam na Słońcu, a obfitością izotopu w materiale botanicznym powstałym w czasie 1300 lat. Badacz ten porównał wyniki pomiarów i wartości liczb Wolfa uśrednione w interwałach o długości 50 lat, co zmniejszyło skalę ewentualnej zmienności wynikającą z istnienia podstawowego cyklu słonecznego.

Analiza jeszcze wcześniej powstałego drewna jedynie utwierdziła Eddy’ego w poglądzie, że długie siedemnastowieczne minimum nie było wyjątkiem. Opinia ta przyczyniła się do upowszechnienia interpretacji zjawiska, według której plamy i zorze w tym czasie były nieliczne, podczas gdy zastosowane wówczas metody obserwacji astronomicznych (Picard, de La Hire, Flamsteed) nie mogą świadczyć o istnieniu wówczas systematycznego programu obserwacji powierzchni dziennej gwiazdy i tym samym o zainteresowaniu dostrzeżeniem mniejszych plam. Z czasem plamom słonecznym mniej uwagi poświęcał także Heweliusz, co jest widoczne w późniejszych zapisach zamieszczonych w jego katalogu pomiarów astrometrycznych ${ }^{289}$.

Wnioski Eddy'ego napotkały zresztą na natychmiastowy opór w postaci publikacji Christophera Cullena, cytującego pracę Xu Zhentao i Jiang Yaotiao ${ }^{290}$, oraz Landsberga ${ }^{291}$, którzy powoływali się na nieznane wcześniej opisy plam dostrzeżonych w Azji i Europie w okresie Minimum. Także Link, analizując opisy zorzowe, był przekonany o ciągłości cyklu jedenastoletniego w tym czasie ${ }^{292}$, zaś Landsberg brak relacji w dziennikach Kircha o plamach z ostatniej dekady XVII w. skomentował słowami, że ten „widocznie nie miał teleskopu”293.

Do chwili obecnej zostało zgromadzonych wystarczająco wiele przesłanek skłaniających ku przypuszczeniu, że poziom aktywności plamowej Słońca w czasie Minimum Maundera mógł być taki, jak rejestrowany współcześnie, zaś obserwowane wówczas przez duże lunety plamy nie różniły się bardzo od widywanych w pozostałych okresach historycznych. Wydaje się to potwierdzać także ciągłość zapisu cykliczności 11-letniej widoczna m.in. w warstwach lodowców utworzonych w drugiej połowie XVII w., zawierających izotop Be10 wytwarzany w ziemskiej atmosferze przez promieniowanie kosmiczne ${ }^{294}$.

${ }^{288}$ M. Stuiver: Variations in Radiocarbon Concentration and Sunspot Activity, „Journal of Geophysical Research" t. 66: 1961 nr 1 s. 273-276.

${ }^{289} \mathrm{~J}$. He weli us z: Machina coelestis..., ks. III, s. 1-30.

${ }^{290}$ Ch. Cullen: Was there a Maunder Minimum?, „Nature” t. 283: 1980 s. 427-428.

${ }^{291}$ H.E. Land s berg: dz. cyt. s. 181-191.

${ }^{292}$ F. Lin k: Solar cycles... s. 176-177.

${ }^{293}$ Uwaga pod tabelą 1; H.E. Lan d sberg: dz. cyt. s. 184.

${ }^{294}$ J. Beer, S. Tobias, N. Weiss: An active Sun throughout the Maunder Minimum, „Solar Physics" t. 181: 1998 s. 237-249. 
Spostrzeżenie dotyczące pojawiania się w trakcie Minimum Maundera plam wyłącznie na półkuli południowej ${ }^{295}$ znalazło swoiste potwierdzenie $\mathrm{w}$ badaniach współczesnych, kiedy to w 2009 r. K. J. Li i in. ${ }^{296}$ stwierdzili istnienie kilkudziesięcioletnich okresów, gdy plamy liczebnie przeważają tylko po jednej stronie słonecznego równika. Faza taka trwała np. w latach 1880-1960 i jeżeli ten długi cykl byłby zachowany w poprzednich stuleciach to w latach 1640-1720 plamy powinny się grupować właśnie na południowej półkuli Słońca, również te największe.

\section{LITERATURA}

E. Baiad a, R. Merighi: The revival of solar activity after Maunder Minimum in reports and observations of E. Manfredi, „Solar Physics” t. 77: 1982 s. 357-362.

N. Bion: Des observations des Taches du Soleil [w:] L'usage des globes célestes et terrestres, et des sphéres suivant les différens systémes du monde, Paryż 1717.

R. B oyle: An Intimation of divers Philosophical particulars, now undertaken and consider'd by Several Ingenious and Learned men; here inserted to excite others to joyn with them in the same or the like Attempts and Observations, „Philosophical Transactions” t. 6: 1671 s. 22162217.

J. Heweliu s z: Selenographia sive lunae descriptio, Gdańsk 1647.

J. Heweliusz: Machina coelestis, Gdańsk 1673, ks. I.

J. Heweliusz: Machina coelestis, Gdańsk 1679, ks. III.

G.D. Cassini: New Observations of Spots in the Sun; made at the Royal Academy of Paris, the 11, 12 and 13th of August 1671; and English't out of the French, as follows, „Philosophical Transactions" t. 6: 1671 s. 2250-2253.

G.D. Cassini: The Observations of the SPOTS of the SUN, made at the Royal Academy at Paris, Continued; and English't out of French, „Philosophical Transactions” t. 6: 1671 s. 3020-3024.

G.D. Cassini: Description du mouvement ou a fait une tache dans le Soleil sur la fin de Novembre dernier 1676, „Journal des sçavans“ 1676 s. 239-240, wyd. paryskie bez bieżącej numeracji tomów.

G.D. Cassini: Suite des observations faites à l'Observatoire Royal, touchant la Tache qui a paru dans le Soleil, les mois d'Octobre, de Novembre et Decembre derniers, „Journal des sçavans" t. 5: 1677 s. 11-13, wyd. amsterdamskie; w wyd. paryskim s. 8-9.

G.D. Cassini: Observation de plusieurs taches et facules dans le Soleil faite à l'Observatoire Royal par M. Cassini, „Journal des sçavans" t. 6: 1678 nr 21 s. 260-262, wyd. amsterdamskie $\mathrm{z} 1679 \mathrm{r}$.

G.D. Cassini: D'une nouvelle Tache dans le Soleil. Par M. Cassini le fils, „Memoires de mathématique et de physique tirés des registres de l'Académie Royale des Sciences", t. 4: $1702 \mathrm{~s}$. 139-140; wyd. paryskie, bez bieżącej numeracji tomów.

${ }^{295}$ Maunder, cytując w 1890 r. wnioski Spörera, wzmiankuje lata 1672-1704, gdy nie zaobserwowano żadnych plam na północnej półkuli Słońca. E.W. Maunder: Professor Spoerer's Researches on Sun-spots, „Monthly Notices of the Royal Astronomical Society” t. 50: 1890 s. 252.

${ }^{296}$ K.J. Li, P.X. Gao, L.S. Zhan: The Long-term Behavior of the North-South asymmetry of Sunspot Activity, „Solar Physics” t. 254: 2009 s. 145-154. 
A.M. Clerke: A prolonged sunspot minimum, „Knowledge” t. 17: 1894 s. 206-207.

W. Derham: Observations upon the Spots that have been upon the Sun, from the Year 1703 to 1711, „Philosophical Transactions” t. 27: 1710 s. 270-277.

Description d'une tache qui a paru dans le Soleil ce mois de May dernier 1684, „Journal des sçavans" t. 12: 1684 nr 15 197-201, wyd. amsterdamskie z 1709 r.

J.A. Eddy: The Maunder Minimum, „Science” t. 192: 1976 nr 4245 s. 1189-1202.

J. Flam steed: An account of a Spot seen in the Sun from the 25th. of April to the 8th. of May instant, with the line of its Course predicted, if it make a second Return, by I.F. Astron. Reg., „Philosophical Transactions" t. 14: 1684 s. 535-536.

J. Fla mstee d: Historia coelestis Britannica, Londyn 1725.

J. Fla msteed: The correspondence of John Flamsteed, the first Astronomer Royal, t. 1 (lata 1666-1682), red. E.G. Forbes i in., Bristol i Philadelphia 1995.

J. Fla m steed: The correspondence of John Flamsteed, the first Astronomer Royal, t. 2 (lata 1682-1703), red. E.G. Forbes i in., Bristol i Philadelphia 1997.

D.V. Hoyt, K.H. Schatten: Overlooked sunspot observations by Hevelius in the early Maunder Minimum,1653 - 1684, „Solar Physics” t. 160: 1995 s. 371-378. D.V. Hoyt,

K.H. Schatten: Observations of sunspots by Flamsteed during the Maunder Minimum, „Solar Physics" t. 160: 1995 s. 379-385.

D.V. Hoyt, K.H. Sch atten: How well was the Sun observed during the Maunder Minimum?, „Solar Physics” t. 165: 1996 s. 181-192.

G. Kirch: Die Korrespondenz des Astronomen und Kalendermachers Gottfried Kirch (16391710), red. K.D. Herbst, Jena 2006.

L. Křivs ký, K. Pej ml: Solar activity, aurorae and climate in Central Europe in the last 1000 years, „Travaux Géophysiques” t. 33: 1985 s. 77-151.

H.E. Lan d s b erg: Variable Solar Emissions, the "Maunder Minimum" and Climatic Temperature Fluctuations, „Archiv für Meteorologie Geophysik und Bioklimatologie“ t. 28: 1980 seria B s. 181-191.

F. Link: Observations et catalogue des aurores boréales apparues en occident de 1601 à 1700, „Geofysikálni Sbornik” t. 212: 1964 s. 501-550.

J. de Mairan: Traité physique et historique de l'aurore boréale, Paryż 1754, wyd. II.

E. Manfredi: De gnomone meridiano bononiensi ad divi Petronii, Bolonia 1736.

E.W. Maund er: Professor Spoerer's Researches on Sun-spots, „,Monthly Notices of the Royal Astronomical Society" t. 50: 1890 s. 251-252.

E.W. Mau nd er: A prolonged sunspot minimum, „Knowledge” t. 17: 1894 s. 173-176.

E.W. Ma under: The Prolonged Sunspot Minimum, 1645-1715, „The Journal of the British Astronomical Association" t. 32: 1922 s. 140-145.

P.C. Le Mo nnier: Histoire celeste ou recueil de toutes les observations astronomiques faites par ordre du Roy, Paryż 1741.

Observation d'une Nouvelle tâche dans le Soleil, „Journal des sçavans“ t. 6:1678 nr 8 s. 9091, wyd. amsterdamskie z 1679 r.

Z.L. Pszczółkowska: Korespondenci Jana Heweliusza [w:] Jan Heweliusz, red. M. Pelczar i J. Włodarczyk, Radom 2011, s. 159-198.

J.C. Ribes, E. N esm e-Ribes: The solar sunspot cycle in the Maunder minimum AD 1645 to $A D$ 1715, „Astronomy and Astrophysics” t. 276: 1993 s. 549-563. 
W. So on, S.H. Ya skell: The Maunder Minimum and the Variable Sun-Earth connection, Singapur 2003.

G. S pö re r: Ueber die Periodicität der Sonnenflecken seit dem Jahre 1618, vornehmlich in Bezug auf die heliographische Breite derselben, und Hinweis auf eine erhebliche Störung dieser Periodicität während eines langen Zeitraumes, „Vierteljahresschrift Astronomische Gesselshaft (Leipsig)" t. 22: 1887 s. 322-329.

G. Spörer: Ueber die Periodicität der Sonnenflecken seit dem Jahre 1618, vornehmlich in Bezug auf die heliographische Breite derselben, und Nachweis einer erheblichen Störung dieser Periodicität während eines langen Zeitraumes, „Nova Acta der Kaiserliche Leopoldinisch - Carolinische Deutschen Akademie der Naturforscher" t. 53: 1889 nr 2 s. 282-324.

Stannyan: Observations made by Captain Stannyan of the Spots that appear'd upon the Body of the Sun in the Months of May, June and July, in the year 1704. Communicated by Mr Hodgson, F. R. S., „Philosophical Transactions” t. 24: 1704-1705 s. 1756-1762.

J.M. Vaquero, M. Vázquez: The Sun Recorded Through History: Scientific Data Extracted from Historical Documents, Berlin 2009.

A.D. Wittmann, Z.T. Xu: A catalogue of sunspot observations from 165 BC to AD 1684, „Astronomy and Astrophysics Supplement Series” t. 70: 1987 s. 83-94.

R. Wolf: Histoire et Mémoires de l'Académie royale des Sciences. Depuis son établissement en 1666 jusqu'à 1699. Vol. 1-11., „Mittheilungen über die Sonnenflecken“ z. 11: 1860 czerwiec s. 30-31.

R. Wolf: Histoire de l'Académie royale des Sciences. Année 1699-1790, „Mittheilungen über die Sonnenflecken“" z. 111860 czerwiec s. 31-38.

[Komunikat bez tytułu i nazwiska autora]: „Histoire de l’Académie Royale des Sciences“, t. 2: 1733 s. 264. 